\title{
THE REFORMULATION OF ALGORITHM FOR CALCULATING STAR'S POSITION AS THE SIGN OF ISYA AND FAJR PRAYER TIMES
}

\author{
M. Syaoqi Nahwandi
}

Universitas Islam Negeri Walisongo, Semarang

nahwandy27@gmail.com

\begin{abstract}
The position of the stars in the sky was used by Islamic Astronomy scholars as a sign of early Isya and Fajr prayers. This method is an alternative that was used in the past when there has not been an advanced time keeping tool like nowadays, especially for locations where syafaq and fajr shâdiq phenomena cannot be observed. Some of the algorithms used for calculating the star's position as a sign of early Isya and Fajr prayers are still fairly approximation (taqribi). So it requires a reformulation of the algorithm to make it is suitable for use in this period. This study resulted two offers of algorithms which are obtained by reformulating al-Buraidi's method and al-Hâsib's: First, the culmination of stars. Second, star's altitude and azimuth. Accuracy test of reformulation of the algorithm compared by stellar observations shows that the results in reformulation of algorithm for calculating star's position as the sign of early Isya and Fajr prayer time are quite accurate with accuracy in units of arc minutes.
\end{abstract}

\section{Keywords : Star's Position, Prayer Times, Reformulation of Algorithm}

\section{Abstrak}

Posisi bintang-bintang di langit pernah dijadikan oleh para ahli ilmu Falak sebagai penanda masuknya awal waktu salat Isya dan Subuh. Metode ini merupakan alternatif yang digunakan di masa lalu saat belum ditemukannya alat penanda waktu yang maju seperti di zaman ini, terutama untuk lokasi yang tidak dapat melihat fenomena syafaq dan fajar sâdiq. Beberapa algoritma yang digunakan dalam perhitungan posisi bintang penanda awal waktu salat Isya dan Subuh masih sederhana dan dengan tingkat akurasi taqribi. Sehingga memerlukan proses reformulasi algoritma agar layak digunakan di masa ini. Penelitian ini menghasilkan dua tawaran algoritma perhitungan yang merupakan hasil reformulasi dari metode milik al-Buraidî dan al-Hâsib: Pertama, kulminasi bintang. Kedua, ketinggian dan azimuth bintang. Uji akurasi hasil reformulasi algoritma ini dengan pengamatan bintang 
menunjukan bahwa hasil reformulasi algoritma posisi bintang penanda awal waktu salat Isya dan Subuh cukup akurat dengan tingkat akurasi dalam satuan menit busur.

Kata Kunci: Posisi bintang, Waktu Salat, Reformulasi Algoritma

\section{A. Introduction}

The regularity of star movements at night was once used by Falakiyun or Muslim astronomers as an alternative method to determine the beginning of the Isya and Fajr prayer times. This method was used by medieval astronomers to determine the beginning of the Isya and Fajr prayer times at locations that could not see syafaq. Various methods of calculating the position of stars as signs of Isya and Fajr prayer times that have been formulated by several medieval Muslim astronomers have different levels of accuracy. Some of the algorithms ${ }^{1}$ used are still very simple and classified as approximate method (taqribi) because they have not used the rules of the spherical trigonometry formula. This certainly leads to the inaccuracy of the classical method of determining the beginning of Isya and Fajr prayer times with the position of the stars. However, this method is very unique and becomes a treasure of the creativity of medieval Muslim astronomers who are too fond to forget. So that research needs to be done to reformulate ${ }^{2}$ the algorithm for calculating the position of stars as the signs of the Isya and Fajr prayer times so that they can be used in the present.

The determination of prayer times in the time of the Holy Prophet and early Islamic era only relied on direct observation which was not easily to be done. At that era, the only way to ensure the time of prayer is to observe the Sun and or the stars in the sky. ${ }^{3}$ This condition encourages Muslims, especially Muslim astronomers of medieval era to formulate mathematical prayer times. The Scholars or Muslim astronomers who pursue the determination of prayer times with the position of celestial bodies known as al-muwaqqit or al-mîqâtî. ${ }^{4}$

\footnotetext{
${ }^{1}$ Algorithms are sequences of steps to solve problems that are arranged systematically and logically. Look at Departemen Pendidikan Nasional, Kamus Besar Bahasa Indonesia, (Jakarta: Pusat Bahasa, 2008), p. 41

${ }^{2}$ Reformulation is to reformulate an old formulation or concept that is no longer appropriate.

${ }^{3}$ Ehsan Masood, Ilmuwan-Ilmuwan Muslim Pelopor Hebat di Bidang Sains Modern, Trans: Fahmy Yamani, (Jakarta: PT Gramedia Pustaka Utama, 2009), 96. Also look at Arwin Juli Rakhmadi Butar-Butar, Khazanah Astronomi Islam Abad Pertengahan, (Purwokerto: UM Purwokerto Press, 2016), p. 452

${ }^{4}$ Arwin Juli Rakhmadi Butar-Butar, Khazanah..., p. 452
} 
During the development of Falak science, Muslim astronomers used the stars not only to determine direction but also as a reference for determining the time at night. One of the leading Muslim astronomers who used the stars as the sign of Fajr prayer time was al-Juzâmî. In his book, al-Juzâmî uses the culmination of the stars which are found in manâzil al-Qamar as the sign of early Fajr prayer time. ${ }^{5}$ In searching Islamic astronomy manuscripts, David A. King found $z \hat{\imath} \hat{j}^{6}$ by Nasîr al-Dîn al-Misrî which contains astronomical tables for determining the time of day using the Sun and determining the time of night using stars. Determination of these times is based on the height of celestial bodies at that location. The table contains 250,000 data collected and adopted by Najm al-Din al-Misri. ${ }^{7}$

In the modern era, research in the field of 'ilm al-Mîqât can be said to be neglected and almost forgotten. Only a handful of researchers and historians conduct research in this field. ${ }^{8}$ Presumably this is caused by the conveniences related to the determination of prayer time schedule using a time system that has been universally standardized in the modern era. So the method of calculating the position of stars as the signs of early Isya and Fajr prayer times which is one of the studies in Mîqât is forgotten. Though some of these methods have not been thoroughly researched and have the potential to be developed so that they can be used in the present.

\section{B. Research Method}

Based on this, the author is interested in conducting research on several methods of calculating the position of stars as the signs of early Isya and Fajr prayer times that have been used in the past and reformulating the algorithm so that it remains suitable for use in the present. In this study, the author used a qualitative method. The approach that used was the library research approach. This research sought to uncover

\footnotetext{
${ }^{5}$ Julio Samso, "Lunar Mansions and Time Keeping in Western Islam”, Suhayl -Journal for the history of the exact and natural sciences in Islamic Civilisation, Vol. 8, (2008):121-161

${ }^{6} \mathrm{Zij}$ is a word derived from Sanskrit which is included in Arabic and Persian which means astronomical tables. But in fact most zij not only contain tables, there are also discussions about theory, chronology, extensive explanation of astronomy, and other related subjects. Look at Susiknan Azhari, Ensiklopedi Hisab Rukyat, (Yogyakarta: Pustaka Pelajar, 2012), p. 246

${ }^{7}$ David A. King, in Synnchrony with the Heavens Vol. I: The Call of The Muezzin, (Leiden: Koninklijke Brill NV, 1990), 60-66

${ }^{8}$ Arwin Juli Rakhmadi Butar-Butar, Khazanah..., p. 452
} 
the methods and algorithms in calculating the star position as the signs of early Isya and Fajr prayer time that had been formulated by al-Buraidî and al-Hâsib in their books. Then applied and developed with reference to the calculation of prayer time in Ilmu Falak 1 by Slamet Hambali ${ }^{9}$, the Sun's data from Ephemeris Hisab Rukyat $2019^{10}$ book, as well as modern star data obtained from The Nautical Almanac of Stars book. ${ }^{11}$ After the reformulated algorithm in calculating star position as the signs of Isya and Fajr prayer times is obtained, the calculation results are tested using observation.

\section{Discussion}

\section{1. Preliminary Determination of Isya and Fajr Prayer Times in Hadith}

In the hadith, it has been mentioned quite clearly about how to determine the beginning of prayer times by looking at natural signs. One of these traditions is as follows:

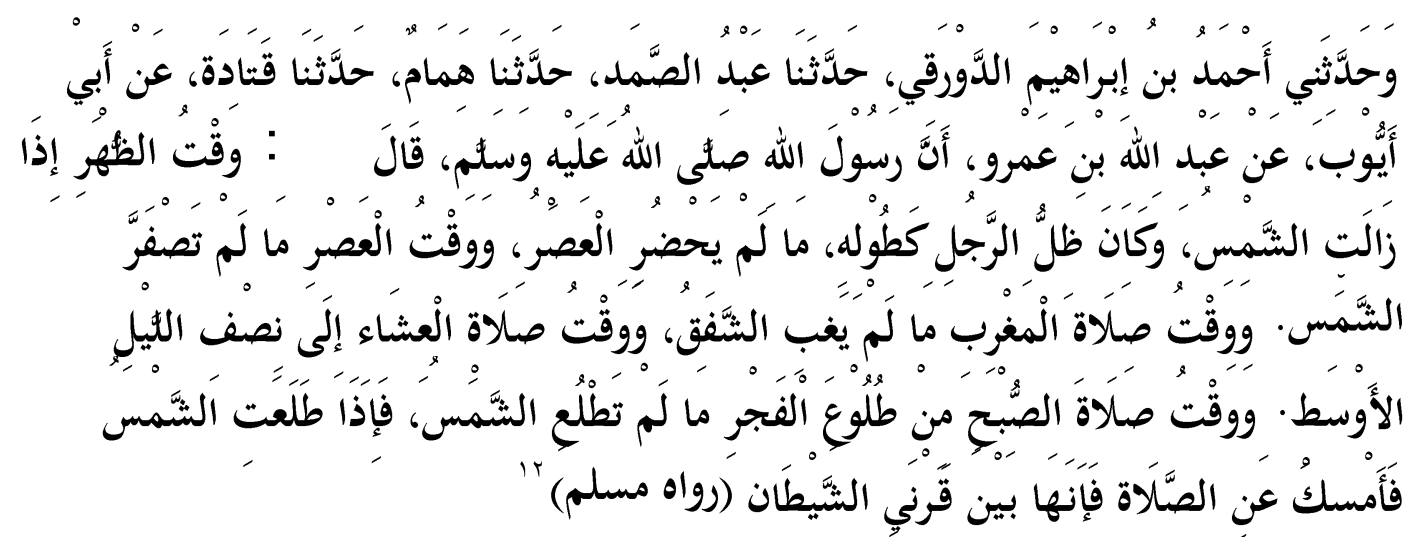

"Ahmad bin Ibrâhîm al-Dauraqî has told me,' Abd al-Samad has told us, Hamâm has told us, Qatâdah has told us, from Abû Ayyûb, from Abdullâh bin 'Amr, that the Messenger of Allah. Said: "The Zhuhur prayer is when the Sun slips to the length of a person's shadow as high as before the Asar prayer time. Asar prayer time is while the Sun is not yet yellowing. The Maghrib prayer time is while the syafaq has not disappeared, and the time of Isya prayer until midnight, and the time of Fajr prayer since dawn until the sun has not yet risen. If the sun rises, then refrain from praying because when the sun rises between the two devil's horns." (Muslim)

\footnotetext{
${ }^{9}$ Slamet Hambali, Ilmu Falak 1, (Semarang: Program Pascasarjana IAIN Walisongo Semarang), 2011

${ }^{10}$ Direktorat Urusan Agama Islam dan Pembinaan Syariah, Ephemeris Hisab Rukyat 2019, (Jakarta: Kementerian Agama RI), 2018

${ }^{11}$ Enno Rodegerdts, The Nautical Almanac of Stars, (London: HM Nautical Almanac Office), 2019

${ }^{12}$ Abû al-Husain Muslim bin al-Hajjâj al-Qusyairî al-Naisâbûrî, Sahîh Muslim, (Beirut: Dâr Ihyâ al-Turâs al-Arabiyah, 2010), vol 1, no hadith: 173, p. 427
} 
From the script of the hadith, it can be concluded that the determination of early Isya and Fajr prayer times can be done through observing natural signs in the form of disappearance of syafaq and the appearance of fajr sâdiq. However, there are differences of opinion regarding the meaning of syafaq and fajr sâdiq.

In Lisân al-Arab it is mentioned that the meaning of syafaq is the remnant of the sun's rays and the redness that is seen in the early evening at sunset until the coming of Isya. Al-Khalîl said that syafaq was reddish in the sky from sunset to the time of Isya. But some scholars of Islamic jurisprudence say that syafaq is white, because the redness in the sky will disappear when the sky becomes dark and leaves white syafaq. So that the disappearance of white syafaq is a sign of the time of Isya prayer. $^{13}$

While the meaning of fajr sâdiq sadiq in the book of Zâd al-Mustaqni' fi ikhtisâr al-Muqni' mentioned that the fajr sâdiq meant is the second fajr or dawn marked by the appearance of white light across the eastern horizon. ${ }^{14}$ It is different from what was mentioned in Lisân al'Arab that the fajr sâdiq is the reddish rays of the eastern horizon in the black night sky. The fajr is twofold: that which rises like a wolfs tail is called the fajr kâz \ib, the second is that which stretches and spreads along the eastern horizon and becomes a time forbidden to eat and drink for those who fast. The second is called fajr sâdiq. Al-Jauhari said that fajr sâdiq at the end of the night is like syafaq at the beginning of the night. ${ }^{15}$

\section{C.2. Legal Basis for the Use of Stars as Sign of Early Isya and Fajr Prayer Times}

In the hadith, the prophet Muhammad has provided a way to determine the beginning of prayer times by observing natural signs that are quite clear in their explanations. However, some Muslim astronomers offer an alternative method to determine the beginning of the Isya and Fajr prayer times with the help of stars that

13 Jamâl al-Dîn Muhammad bin Mukrim bin Manz \ûr al-Ifrîqî al-Misrî, Lisân al-'Arab, (Beirut: Dâr Sâdir, 2010), vol 10, p. 180

${ }^{14}$ Syaraf al-Dîn Abû al-Najâ Mûsâ bin Ahmad al-Hajâwî, Zâd al-Mustaqni' fi ikhtisâr al-Muqni', Riyadl: Madar al-Wathn, tt., p. 40

${ }^{15}$ Jamâl al-Dîn Muhammad bin Mukrim bin Manz \ûr al-Ifrîqî al-Misrî, Lisân..., vol 5, p. 45 
is not mentioned by the Prophet in the Hadith. The following are some interpretations of the verses of al-Qur'an and some Muslim scholars opinion regarding the use of stars as the signs of early Isya and Fajr prayer times:

1. Interpretation of surah al-An'âm verse 96

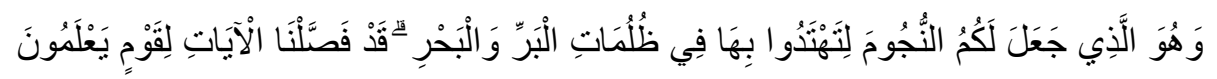

"And He made the stars for you, so that you make them instructions in the darkness on land and in the sea. Verily, We have explained the signs of (We) to those who know." 16

In its interpretation, al-Marâgî said that the Arabs knew the period of planting with the rise of a star. So that with the stars they could align the seasons with the calendar. The stars used were stars of manâzil al-Qamar. Regarding the explanation of the star as a guide in the dark, al-Marâgî said that the instructions that could be known by the Arabs with the star were twofold, namely knowing the time of night and season, and knowing the route of the road and direction. ${ }^{17}$

Based on al-Marâgî's opinion, it can be understood that knowledge of star position and its rising time can be used to determine the time and season. This is not new knowledge used by Muslim astronomers in the Middle Ages. But the knowledge that has long been used by people the Arabs in ancient times and it is a proof that the stars can be used as time marker.

2. Hadith Narrated by Abû Dawûd

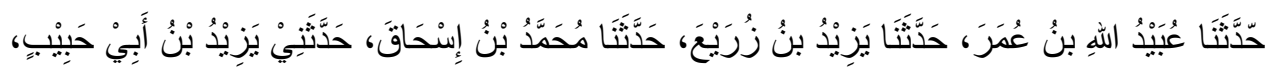

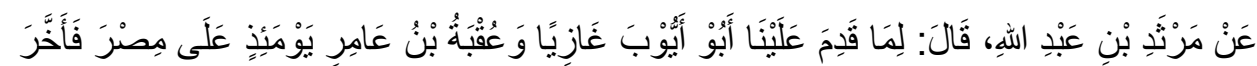

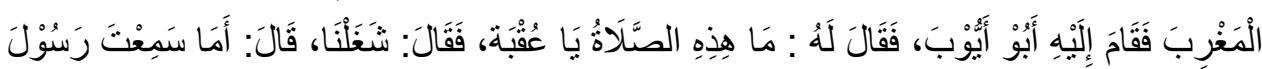

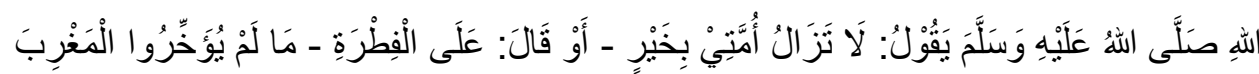

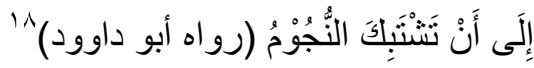

\footnotetext{
${ }^{16}$ Departemen Agama RI, Al-Qur'an dan Terjemahnya, (Jakarta: CV Darus Sunnah, 2007), p. 140

${ }^{17}$ Ahmad Mustafa al-Maragi, Tafsir al-Maragi, (Kairo: Maktabah Mustafa al-Babi al-Halabi, tth), Vol VII, p. 200

${ }^{18}$ Abû Dâwûd Sulaimân bin al-Asy'as al-Sijistânî, Sunan Abî Dâwûd, Riyad: Maktabah al-Ma'ârif li alNasyr wa al-Tauzî̀, 1988, p. 29
} 
“ 'Ubaidullah bin 'Umar has told us, Yazîd bin Zurai' has told us, Muhammad bin Ishâq has told us, Yazîd bin Abî Habîb has told me, from Mars \ad bin Abdilla<h, he said: When Abû Ayyûb came to us at war and 'Uqbah bin' 'A<mir when it was ruler of Egypt then he ended the Maghrib prayer then Abû Ayyûb asked him: What is this prayer, O 'Uqbah? So 'Uqbah answered, We are very busy. Abû Ayyûb said: Did you not hear Rasûlullâh peace be upon him saying: "My people are always in goodness - or fitrah - while they do not end Maghrib prayer until the stars are much like net.” (Narrated by Abû Dâwûd)

In the book of Syarh Misykâh al-Masâbîh, it is mentioned that the hadith is a suggestion to hasten to perform the Maghrib Prayer before the stars in the sky are clear, as explained and carried out by the Companions of the Prophet and Tâbi'în. The word tasytabik al-Nujûm according to Ibn Mâlik means that many stars in the sky are visible and intermittent so that they can be likened or much like a net (syabakah).. ${ }^{19}$

According to Ibn Khuzaimah, the deadline for conducting Maghrib prayer is the disappearance of syafaq. The phenomenon of isytibâk al-Nujûm occurs before the disappearance of syafaq and there is a fairly long time lag. Shortly after isytibâk al-Nujûm, one can carry out more than four raka'at of prayer before syafaq disappears. ${ }^{20}$

In this discussion, the author prefers the interpretation of isytibâk alNujûm as a result of the sky starting to get really dark so that the stars appear to be scattered in the sky. The stars that appear bright can be the first signs of Isya prayer if they are seen clearly in the dark western sky after the disappearance of syafaq.

${ }^{19}$ Muhammad bin Abdullah al-Khatîb al-Tibrîzî, Syarh Misykâh al-Masâbîh, (Beirut: Dar al-Kutub alIlmiyah, 2001), Vol II, p. 291

${ }^{20}$ Abû Bakr Muhammad bin Ishâq bin Khuzaimah, Sahîh Ibn Khuzaimah, (Riyad: al-Maktabah alIslami, 1980), Vol 1, p. 2017 
3. Syihâb al-Dîn al-Sanhâjî al-Qarafî’s opinion

In one of the subsection of his book, Syihâb al-Dîn al-Sanhâjî al-Qarafî discusses things that are compulsory and are not required to be learned from stars. According to him, the clearest clue about the direction of Qibla comes from the stars. So the law of studying Falak or Astronomy to know the direction of Qibla is compulsory. Syihâb al-Dîn al-Sanhâjî al-Qarafî also quoted Ibn Rusyd's opinion that things that can be obtained from studying astronomy is a way to use stars to find the direction of Qibla, the division of time at night, and to know the direction in the darkness of land and sea, and to know the positions of stars, the time of rising and setting. That is all can be judged as sunnah in accordance with Sûrah al-An'âm verse $96 .^{21}$

Syihâb al-Dîn al-Sanhâjî al-Qarafî also said that what can be raised from the important function of the use of stars is to know the times of prayer and that is judged as fard kifâyah because of the permissibility of taqlìd in determining prayer times. Thus, knowing the prayer time is mandatory and learning how to find out is fard kifâyah. ${ }^{22}$

Based on some Muslim scholars' opinion and their interpretation on al-Qur'an and hadith, it can be concluded that some Muslim scholars allow the using stars as one method to determine the beginning of Isya and Fajr prayer time. In this discussion, the author argued that the use of stars as the sign of early Isya and Fajr prayer times performed by Muslim astronomers can be functioned like calculation for determining the prayer times in the present. These methods can be used as a referee to determine the prayer times at locations that cannot see the disappearance of syafaq and the appearance of fajr sâdiq and must use accurate star observation tools.

Related to the reckoning of the early prayer times commonly used by Muslim astronomers or Falak experts, Ahmad Izzuddin said that the validity and accuracy of

\footnotetext{
${ }^{21}$ Syihâb al-Dîn Ahmad bin Idrîs bin abd al-Rahmân al-Sanhâji al-Qarafî, Anwâr al-Burûq fî anwâ alFurûq, (Kairo: Dar Ihya al-Kutub al-'Arabiyah, 2010), Vol 4, p. 258

${ }^{22}$ Syihâb al-Dîn Ahmad bin Idrîs bin abd al-Rahmân al-Sanhâji al-Qarafî, Anwâr..., p. 258-259
} 
the results had proven to be very close to the direct observations. According to him, the results of the early reckoning when the prayer using modern algorithms is very close to the time the appearance of natural signs of early prayer time. Then the results of calculation of prayer times using modern algorithms has undoubted level of accuracy. So in this case, the calculation (hisâb) and observation of natural signs for early prayer times (ru'yah), both have the same level. ${ }^{23}$

\section{C.3. The Calculation Methods of Star Position as The Sign of Early Isya and Fajr Prayer Times in Classical Falak Literature}

The use of stars to determine the time at night that has been made by medieval Muslim astronomers has a variety of different methods. Some of these methods have been studied by several researchers from the west, such as David A. King and Julio Samso. So in this paper, the author only wrote the method of determining the time using the stars from two manuscripts that were not discussed in the researches belonging to David A. King and Julio Samso.

The following are some methods for determining the beginning of Isya and Fajr by using the stars position that are the focus of the discussion in this paper:

1. Muhammad bin Muhammad al-Buraidî’s Method

In Risâlah fî al-Burûj wa al-Manâzil: Farâid Jauhariyah fî Fawâid alMîqâtiyah, Muhammad bin Muhammad al-Buraidî gave a way of approximate method (taqrîîi) in determining the Fajr time with the help of Manâzil alQamar:

"Know that the manâzil al-Qamar amounts to 28. Indeed, half of Manâzil alQamar is always above the horizon and the other half is below the horizon. If one manzilah or one degree from it sinks, then one manzilah or one degree of reverse will rise in place. And the middle manzilah from the manâzil above the horizon is in the midline of the day. The manzilah is the seventh manzilah

${ }^{23}$ Ahmad Izzuddin, Fiqih Hisab Rukyah, (Jakarta: Penerbit Erlangga, 2007), p. 39 
calculated from the rising or setting manzilah. and the manzilah which culminates at Fajr is the seventh manzilah that is rising. ${ }^{24}$

From the explanation above, the author concludes that the method used by al-Buraidî to know the coming of Fajr time is by reference to the culmination of one of the Manâzil al-Qamar. In his book, al-Buraidî does not exemplify the method of calculating Fajr time with that method. Al-Buraidî only mentions that the Manâzil al-Qamar which is used as a sign of the coming of Fajr time is the seventh Manâzil al-Qamar calculated from the manzilah or zodiac that is above the horizon.

In this discussion, the author argued that al-Buraidî's method has a low accuracy if it is used to determine the beginning of Fajr prayer time. To prove it, the author applied al-Buraidî's method by using the Sun's data from Ephemeris Hisab Rukyat 2019 book and the table Manâzil al-Qamar from alKhulasah al-Wafiyah ${ }^{25}$ by Zubair Umar al-Jailani. For example, the author used March 20, 2019. Details of the calculation are as follows:

a. Required data:

$$
\begin{aligned}
& \text { Latitude of place }(\phi) \quad: 6^{\circ} 59^{\prime} 43^{\prime \prime} \mathrm{S} \\
& \text { Longitude of place }\left(\lambda_{\mathrm{t}}\right) \quad: 110^{\circ} 19^{\prime} 55^{\prime \prime} \mathrm{E} \\
& \text { Elevation of place }(\mathrm{tt}): 59 \text { masl }
\end{aligned}
$$$$
\text { Sun's declination }(\delta) \quad:-0^{\circ} 16^{\prime} 47^{\prime \prime}
$$$$
\text { Equation of time (e) } \quad:-0^{\mathrm{h}} 7^{\mathrm{m}} 7^{\mathrm{s}}
$$

b. Calculating Sun's altitude at Fajr ${ }^{26}$

$$
\begin{aligned}
\mathrm{h}_{\mathrm{sb}} & =-19-\left(\mathrm{ref}+\mathrm{sd}+0^{\circ} 1,76^{\prime} \times V_{\mathrm{tt}}\right) \\
& =-19-\left(0^{\circ} 3{ }^{\prime}+0^{\circ} 16^{\prime}+0^{\circ} 1,76^{\prime} \times \sqrt{86}\right) \\
& =-19^{\circ} 32^{\prime} 31,13^{\prime \prime}
\end{aligned}
$$

c. Calculating Sun's hour angle at Fajr ${ }^{27}$

\footnotetext{
${ }^{24}$ Muhammad ibn Muhammad al-Buraidî, Risâlah fî al-Burûj wa al-Manâzil; Farâid Jauhariyah fî Fawâid al-Mîqâtiyah, Manuscript scanned by Library of Congress, 1831

${ }^{25}$ In al-Khulasah al-Wafiyah book, it is mentioned that the reference of manazil al-Qamar's table used from 1350 Hijriah. Look at Zubair Umar al-Jailani, al-Khulasah al-Wafiyah, (Kudus: Menara Kudus, tt), p. 265

${ }^{26}$ Slamet Hambali, Ilmu..., p. 147

${ }^{27}$ Slamet Hambali, Ilmu..., p. 147
} 


$$
\begin{aligned}
\operatorname{Cos} \mathrm{t}_{\mathrm{s}} \quad & =-\tan \phi \times \tan \delta+\sin \mathrm{h}_{\mathrm{sb}}: \cos \phi: \cos \delta \\
= & -\tan -6^{\circ} 59^{\prime} 43^{\prime \prime} \times \tan -0^{\circ} 16^{\prime} 47^{\prime \prime}+\sin -19^{\circ} 32^{\prime} 31,13^{\prime \prime} \\
& : \cos 6^{\circ} 59^{\prime} 43^{\prime \prime}: \cos -0^{\circ} 16^{\prime} 47^{\prime \prime} \\
= & 110^{\circ} 11^{\prime} 36,71^{\prime \prime}
\end{aligned}
$$

d. Early Fajr prayer time:

$$
\text { Fajr } \quad \begin{aligned}
= & 12-\mathrm{e}+(\lambda \mathrm{d}-\lambda \mathrm{t}): 15-\mathrm{t}_{\mathrm{s}}: 15 \\
= & 12--^{\mathrm{h}} 7^{\mathrm{m}} 37^{\mathrm{s}}+\left(105^{\circ}-110^{\circ} 19^{\prime} 55^{\prime \prime}\right): 15 \\
& -110^{\circ} 11^{\prime} 36,71^{\prime \prime}: 15 \\
= & 4: 27: 21,83 \mathrm{WIB}
\end{aligned}
$$

e. Interpolation of Sun's Longitude $(\lambda \mathrm{M})$ data at Fajr

$$
\begin{array}{ll}
\lambda \mathrm{M} 1 \text { (21 GMT) } & : 359^{\circ} 3^{\prime} 2^{\prime \prime} \\
\lambda \mathrm{M} 2(22 \mathrm{GMT}) & : 359^{\circ} 5^{\prime} 19^{\prime \prime} \\
\text { interpolation } & =\mathrm{A}+\mathrm{k} \times(\mathrm{B}-\mathrm{A}) \\
= & 359^{\circ} 3^{\prime} 2^{\prime \prime}+0: 27: 21,83 \times\left(359^{\circ} 5^{\prime} 19^{\prime \prime}\right. \\
& \left.-359^{\circ} 3^{\prime} 2^{\prime \prime}\right) \\
= & 359^{\circ} 4^{\prime} 4,48^{\prime \prime} \\
= & 11^{\mathrm{b}} 29^{\circ} 4^{\prime} 4,48^{\prime \prime}
\end{array}
$$

f. Determining Sun's manzilah at Fajr

The Sun's Longitude at Fajr is $359^{\circ} 4^{\prime} 4,48^{\prime \prime}$ or $11^{\mathrm{b}} 29^{\circ} 4^{\prime} 4,48^{\prime \prime}$. Based on the table of Manâzil al-Qamar in al-Khulâsah al-Wafiyah book, at that time the position of the Sun was at $0^{\circ} 29^{\prime} 4,48^{\prime \prime}$ from manzilah al-Syaratain or the first manzilah. ${ }^{28}$.

g. Determining the manzilah that culminates at Fajr

According to al-Buraidî, the determination of manzilah that culminates at Fajr is by counting seven manâzil from the Sun's manzilah at Fajr. Then according to al-Buraidî's method, the manzilah mutawassitah or the manzilah that culminates is Sa'd al-Z||abih, namely the $22^{\text {nd }}$ manzilah.

${ }^{28}$ Based on al-Manazil table in al-Khulashah al-Wafiyah, the longitude of al-Syaratain is $11^{\mathrm{b}} 28^{\circ} 35^{\prime}$. Look at Zubair Umar al-Jailani, al-Khulasah..., p. 265 
The author tried to check the altitude of the star Sa'd al-Z||abih or Prima Giedi ${ }^{29}$ by using Stellarium software $0.18 .2 .^{30}$ The result was that at 4:27:22 WIB the altitude of the Prima Giedi star was calculated 3448’35,4”. The altitude of Prima Giedi star at Fajr is still quite low and far from it's culmination altitude, which is $90-[\delta-\phi]=84^{\circ} 32^{\prime} 58,5^{\prime \prime}{ }^{31}$

The author included a comparison table of the seventh manzilah's altitude from the Sun's position at Fajr with it's culmination altitude:

\begin{tabular}{|c|c|c|c|c|c|c|}
\hline No & Date & $\begin{array}{c}\text { Fajr } \\
\text { Time } \\
\text { (WIB) }\end{array}$ & $\begin{array}{l}\text { Sun's } \\
\text { manzilah }\end{array}$ & $\begin{array}{c}\text { The Seventh } \\
\text { manzilah }\end{array}$ & $\begin{array}{c}\text { The altitude } \\
\text { of seventh } \\
\text { manzilah }\end{array}$ & $\begin{array}{c}\text { The } \\
\text { culmination } \\
\text { altitude }\end{array}$ \\
\hline 1 & $20 / 03 / 2019$ & $4: 27: 22$ & $\begin{array}{c}\text { al-Syaratain } \\
\text { (Sheratan) }\end{array}$ & $\begin{array}{l}\text { Sa'd al-Z |abih } \\
\text { (Prima Giedi) }\end{array}$ & $34^{\circ} 48^{\prime} 35,4^{\prime \prime}$ & $84^{\circ} 32^{\prime} 58,5^{\prime \prime}$ \\
\hline 2 & $22 / 06 / 2019$ & $4: 27: 42$ & $\begin{array}{l}\text { al-Han'ah } \\
\text { (Alhena) }\end{array}$ & $\begin{array}{c}\text { Al-Fargh al- } \\
\text { S|ani } \\
\text { (Alpheratz) }\end{array}$ & $48^{\circ} 37^{\prime} 12,4^{\prime \prime}$ & $53^{\circ} 48^{\prime} 46,2 ”$ \\
\hline 3 & $22 / 9 / 2019$ & $4: 13: 4$ & $\begin{array}{c}\text { al-Sarfah } \\
\text { (Denebola) }\end{array}$ & $\begin{array}{c}\text { Al-Haq'ah } \\
\text { (Meissa) }\end{array}$ & $67^{\circ} 6 ' 8,5^{\prime \prime}$ & $73^{\circ} 3^{\prime} 16,1^{\prime \prime}$ \\
\hline 4 & $22 / 12 / 2019$ & $3: 57: 31$ & $\begin{array}{l}\text { al-Syaulah } \\
\text { (Shaula) }\end{array}$ & $\begin{array}{l}\text { Al-Sarfah } \\
\text { (Denebola) }\end{array}$ & $58^{\circ} 32^{\prime} 29,2^{\prime \prime}$ & $68^{\circ} 32^{\prime} 54,2^{\prime \prime}$ \\
\hline
\end{tabular}

Table 1. Comparison of the altitude of the seventh manzilah of the sun at Fajr and its culmination altitude

Based on the table above, it can be concluded that at the time of Fajr, the seventh manzilah of Sun's position has not yet reached its culmination. Here is the table of differences between the culmination time of seventh manzilah from the Sun's position and the Fajr time:

\begin{tabular}{cccccc}
\hline No & Date & $\begin{array}{c}\text { Fajr time } \\
\text { (WIB) }\end{array}$ & $\begin{array}{c}\text { The seventh } \\
\text { manzilah }\end{array}$ & $\begin{array}{c}\text { Its } \\
\text { culmination } \\
\text { time }\end{array}$ & $\begin{array}{c}\text { Time } \\
\text { difference }\end{array}$ \\
\hline 1 & $20 / 03 / 2019$ & $4: 27: 22$ & $\begin{array}{c}\text { Sa'd al-Zabih } \\
\text { (Prima Giedi) }\end{array}$ & $8: 8: 14$ & $3^{\mathrm{h}} 42^{\mathrm{m}} 59^{\mathrm{s}}$ \\
\hline 2 & $22 / 06 / 2019$ & $4: 27: 42$ & $\begin{array}{c}\text { Al-Fargh al-Sani } \\
\text { (Alpheratz) }\end{array}$ & $5: 48: 31$ & $1^{\mathrm{h}} 23^{\mathrm{m}} 26^{\mathrm{s}}$ \\
\hline 3 & $22 / 9 / 2019$ & $4: 13: 4$ & $\begin{array}{c}\text { Al-Haq'ah } \\
\text { (Meissa) }\end{array}$ & $5: 12: 40$ & $1^{\mathrm{h}} 1^{\mathrm{m}} 43^{\mathrm{s}}$ \\
\hline 4 & $22 / 12 / 2019$ & $3: 57: 31$ & $\begin{array}{c}\text { Al-Sharfah } \\
\text { (Denebola) }\end{array}$ & $5: 27: 43$ & $1^{\mathrm{h}} 32^{\mathrm{m}} 35^{\mathrm{s}}$ \\
\hline
\end{tabular}

\footnotetext{
${ }^{29} \mathrm{http}: / /$ www.constellationsofwords.com/stars/Sadalachbia.html accessed on March 20, 2019

${ }^{30}$ Stellarium 0.18 .2 is the latest release software in 2018 produced by the Free Software Foundation, Inc. which features a simulation of sky conditions accompanied by data on the position of celestial objects in that location with other features that are quite complete.

${ }^{31}$ Sa'd al-Z | |abih or Prima Giedi star's declination with reference of apparent equatiorial circle of the date is $\delta=-12^{\circ} 26^{\prime} 44,5^{\prime \prime}$. See https://www.iau.org/public/themes/constellations/ accessed on March 20, 2019
} 
Tabel 2. Differences between the culmination time of the seventh manzilah and

$$
\text { the Fajr time }
$$

Based on the table above, time difference between the culmination time of the seventh manzilah and Fajr time is still quite far. In his book, alBuraidi also mentions that this method is just approximate method (taqrîbî).

Thus, the author concluded that al-Buraidî's method in determining the beginning of Fajr time using Manâzil al-Qamar is less feasible to be used as a method of determining early Fajr time due to the low level of accuracy. Based on the table, the maximum time difference between culmination time of the seventh manzilah and Fajr time is $3^{\mathrm{h}} 42^{\mathrm{m}} 59^{\mathrm{s}}$.

2. Ahmad bin Ghulâmillah bin Ahmad al-Hâsib's Method

In the book of Nuzhah al-Nâzir fî Talkhîs Zîj Ibn al-Syâtir, al-Hâsib explained the determination of time with a star's altitude:

The $39^{\text {th }}$ chapter: calculating the time elapsed and what remains of the night by reference to the altitude of a star. The method is to calculate fad al-Dâir from the star's altitude. If the star's altitude is in the East, then subtract the value of fad al-Dâir ${ }^{32}$ with the matâli' of star ${ }^{33}$. If the star's altitude is in the West, then add fad al-Dâir with matâli' of star. Then the value of matâli' nazîr Juzu' of the Sun is subtracted from the results earlier. That is the time that passes from the setting of the Sun to the measurement of the star's altitude. If you subtract the value of matâli' juzu' of the Sun with this result, then it is the time remaining from the night since the time of measuring the star's altitude. ${ }^{34}$

From the explanation, the author concluded that the method used by alHâsib is to calculate the time interval between sunset and time of measuring

\footnotetext{
${ }^{32} \mathrm{Fad}$ al-Dâir or hour angle is the angle at the celestial pole formed by the intersection of the meridian circle with the time circle through the celestial bodies in the celestial globe. Look at Susiknan Azhari, Encyclopedia ..., p. 195

${ }^{33}$ Matâli' is the plural of the word matla' which means the place of rise. In the celestial sphere coordinate system, the word matla' has the meaning of the celestial right ascension, that is the arc along the equatorial circle which is calculated from the point of Aries to the projection of the celestial body at the equator.

${ }^{34}$ Ahmad bin Ghulâmillah bin Ahmad al-Hâsib, Nuzhah al-Nâzir fî̀ Talkhîs Zî̀ Ibn al-Syâtir, Manuscript scanned by the Library of Congress, Boston, p. 235
} 
the star's altitude, termed by the time has passed from the night. This method also can be used to calculate the time interval between time of observing the star to Sunrise, termed by the time remaining from the night. To prove this method, the author applied it by using the Sun's data from the book of Ephemeris Hisab Rukyat 2019 and star's altitude obtained from Stellarium Software. The calculation details are as follows:

a. Required data:

Latitude of place $(\phi) \quad$ : 6 $60^{\circ}$ ' 43” S

Longitude of place $\left(\lambda_{\mathrm{t}}\right) \quad$ : $110^{\circ} 19^{\prime} 55^{\prime \prime} \mathrm{E}$

Elevation of place $(\mathrm{tt}) \quad$ : 59 masl

Sun's declination $(\delta) \quad:-0^{\circ} 16^{\prime} 47^{\prime \prime}$

Equation of time (e) $\quad:-0^{\mathrm{h}} 7^{\mathrm{m}} 7^{\mathrm{s}}$

Date : : March 20, 2019

Time of observation ${ }^{35} \quad: 22: 8: 25$ WIB

Sun's right ascension $\left(\alpha_{\mathrm{m}}\right): 359^{\circ} 21^{\prime} 16^{\prime \prime}$

Sun's declination $\left(\delta_{\mathrm{m}}\right)^{36} \quad:-0^{\circ} 16^{\prime} 47^{\prime \prime}$

Star name: Regulus

Star's declination $\left(\delta_{\mathrm{b}}\right): 11^{\circ} 52^{\prime} 15.4^{\prime \prime}$

Star's right ascension $\left(\alpha_{b}\right): 152^{\circ} 21$ '8.55"

Star's altitude $\left(\mathrm{h}_{\mathrm{b}}\right) \quad$ : $70^{\circ} 53^{\prime} 53.5^{\prime \prime}$

b. Calculating hour angle of Regulus $\left(t_{b}\right)$ :

Cost $\mathrm{t}_{\mathrm{b}}=-\tan \phi \times \tan \delta_{\mathrm{b}}+\sin \mathrm{h}_{\mathrm{b}}: \cos \phi: \cos \delta_{\mathrm{b}}$

$=-\tan -6^{\circ} 59^{\prime} 43^{\prime \prime} \times \tan 11^{\circ} 52^{\prime} 15,4^{\prime \prime}+\sin 70^{\circ} 53^{\prime} 53,5^{\prime \prime}$

: $\cos -6^{\circ} 59^{\prime} 43^{\prime \prime}: \cos 11^{\circ} 52^{\prime} 15,4^{\prime \prime}$

$=3^{\circ} 0^{\prime} 25,86^{\prime \prime}$

c. Calculating the sum of Regulus' right ascension and its hour angle (alHâsil)

${ }^{35}$ The time that used here is the time that inputted on the Stellarium software.

${ }^{36}$ The value of sun's righr ascension and declination that author used was the Sun's right ascension at 12 WIB. Look at Direktorat Urusan Agama Islam dan Pembinaan Syariah, Ephemeris..., p. 113 
In this section, the author calculated the sum of Regulus' right ascension and its hour angle because on March 20, 2019 at 22: 8: 25 WIB the Regulus star was in the west. This is according to the presentation of the al-Hâsib's method in his book. ${ }^{37}$

$$
\begin{aligned}
\text { al-Hâsil } & =\alpha_{b}+t_{b} \\
& =152^{\circ} 21^{\prime} 8,55^{\prime \prime}+3^{\circ} 0^{\prime} 25,86^{\prime \prime} \\
& =155^{\circ} 21^{\prime} 34,41^{\prime \prime}
\end{aligned}
$$

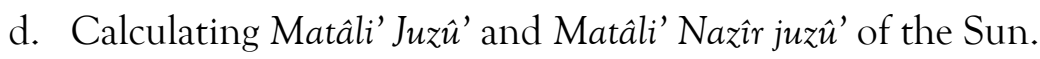

In the book of Nuzhah al-Nâzir fî Talkhîs Zî̀j Ibn al-Syâtir, al-Hâsib did not mention the definition of Matâli' Juz $\hat{u}$ ' of the Sun but al-Hâsib mentioned the steps to calculate it, namely by adding up the value of matâli' of the Sun $\left(\alpha_{\mathrm{m}}\right)$ with the values of Qaus al-Lail (QL) dan Nisf Qaus al-Nahâr (NQN). While Matâli' Nazîr Juzû' of the Sun (MNJM) is the sum of the values of Matâli' Juzĥ' of the Sun (MJM) with $180^{\circ}$ and Nisf Qaus alLail (NQL) and Qaus al-Nahâr (QN). Here are the calculations:

$$
\begin{aligned}
& \operatorname{Cos} \mathrm{NQL}=\tan \phi \times \tan \delta_{\mathrm{m}}{ }^{38} \\
& =\tan -6^{\circ} 59^{\prime} 43^{\prime \prime} \times \tan -0^{\circ} 16^{\prime} 47^{\prime \prime} \\
& =89^{\circ} 57^{\prime} 56,44^{\prime \prime} \\
& \mathrm{QL}=\mathrm{NQL} \times 2 \\
& =89^{\circ} 57^{\prime} 56,44^{\prime \prime} \times 2 \\
& =179^{\circ} 55^{\prime} 52,88^{\prime \prime} \\
& \mathrm{QN}=360^{\circ}-\mathrm{QL} \\
& =360^{\circ}-179^{\circ} 55^{\prime} 52,88^{\prime \prime} \\
& =180^{\circ} 4^{\prime} 7,12^{\prime \prime} \\
& \mathrm{NQN}=\mathrm{QN}: 2 \\
& =180^{\circ} 4^{\prime} 7,12^{\prime \prime}: 2 \\
& =90^{\circ} 2^{\prime} 3,56^{\prime \prime} \\
& \mathrm{MJM}=\alpha_{\mathrm{m}}+\mathrm{QL}+\mathrm{NQN}^{39}
\end{aligned}
$$

\footnotetext{
${ }^{37}$ Ahmad bin Ghulâmillah bin Ahmad al-Hâsib, Nuzhah ..., p. 235

${ }^{38}$ Look at Zubair Umar al-Jailani, al-Khulasah ..., p. 91

${ }^{39}$ Look at Ahmad bin Ghulâmillah bin Ahmad al-Hâsib, Nuzhah ..., p. 235.
} 


$$
\begin{aligned}
& =359^{\circ} 21^{\prime} 16^{\prime \prime}+179^{\circ} 55^{\prime} 52,88^{\prime \prime}+90^{\circ} 2^{\prime} 3,56^{\prime \prime} \\
& =629^{\circ} 19^{\prime} 12,44^{\prime \prime}-360^{\circ} \\
& =269^{\circ} 19^{\prime} 12,44^{\prime \prime} \\
\text { MNJM } \quad & \alpha_{\mathrm{m}}+180^{\circ}+\mathrm{NQL}+\mathrm{QN}^{40} \\
& =359^{\circ} 21^{\prime} 16^{\prime \prime}+180^{\circ}+89^{\circ} 57^{\prime} 56,44^{\prime \prime}+180^{\circ} 4^{\prime} 7,12^{\prime \prime} \\
& =89^{\circ} 23^{\prime} 19,56^{\prime \prime}
\end{aligned}
$$

e. Calculating the elapsed night time (Mâdî)

The next step is calculating the night time that has passed since Sunset until the time of observing Regulus. The calculation is as follows:

Mâdî

$$
\begin{aligned}
& =\text { al-Hâsil }-\mathrm{MNJM}^{41} \\
& =155^{\circ} 21^{\prime} 34,41^{\prime}-89^{\circ} 23^{\prime} 19,56^{\prime \prime} \\
& =65^{\circ} 58^{\prime} 14,85^{\prime \prime}: 15 \\
& =4^{\mathrm{h}} 23^{\mathrm{m}} 52,99^{\mathrm{s}}
\end{aligned}
$$

f. Calculating the remaining time of night (Bâqî)

The next step is calculating the remaining night time from the time of observing Regulus until the time of Sunrise. The calculation is as follows:

Bâqu

$$
\begin{aligned}
& =\text { MJM - al-Hâsil } \\
& =269^{\circ} 19^{\prime} 12,44^{\prime \prime}-155^{\circ} 21^{\prime} 34,41^{\prime} \\
& =113^{\circ} 57^{\prime} 38,02^{\prime \prime}: 15 \\
& =7^{\mathrm{h}} 35^{\mathrm{m}} 50,53^{\mathrm{s}}
\end{aligned}
$$

The conclusion from the calculation is that at a location with latitude $6^{\circ} 59^{\prime} 43^{\prime \prime} \mathrm{S}$ and longitude $110^{\circ} 19^{\prime} 55^{\prime \prime} \mathrm{E}$, when the star Regulus has an altitude of $70^{\circ} 53^{\prime} 53,5^{\prime \prime}$ in the west on March 20, 2019, the time is $4^{\mathrm{h}} 23^{\mathrm{m}}$ $52,99^{\mathrm{s}}$ after the Sunset or it is $7^{\mathrm{h}} 35^{\mathrm{m}} 50,53^{\mathrm{s}}$ before the Sunrise.

Furthermore, the author evaluated the results of the calculations through comparison with calculations in the book of Ilmu Falak 1 by Slamet Hambali. ${ }^{43}$ Here is the comparison table of both methods:

\footnotetext{
${ }^{40}$ Look at Ahmad bin Ghulâmillah bin Ahmad al-Hâsib, Nuzhah ..., p. 235.

${ }^{41}$ Look at Ahmad bin Ghulâmillah bin Ahmad al-Hâsib, Nuzhah ..., p. 235.

${ }^{42}$ Look at Ahmad bin Ghulâmillah bin Ahmad al-Hâsib, Nuzhah ..., p. 235.

${ }^{43}$ Slamet Hambali, Ilmu..., p. 147
} 


\begin{tabular}{|c|c|}
\hline \multirow{4}{*}{1} & Time interval between Sunset and Observation \\
\hline & al-Hâsib's Method \\
\hline & $4^{\mathrm{h}} 17^{\mathrm{m}} 59,78^{\mathrm{s}}$ \\
\hline & difference $=0^{\mathrm{h}} 5^{\mathrm{m}} 53,21^{\mathrm{s}}$ \\
\hline \multirow{4}{*}{2} & Time interval between Observation and Sunrise \\
\hline & al-Hâsib's Method \\
\hline & $7^{\mathrm{h}} 35^{\mathrm{m}} 50,53^{\mathrm{s}}$ \\
\hline & difference $=0^{\mathrm{h}} 2^{\mathrm{m}} 38,76^{\mathrm{s}}$ \\
\hline \multirow{4}{*}{3} & Time of Sunrise \\
\hline & al-Hâsib’s Method \\
\hline & $5: 44: 15,53$ \\
\hline & difference $=0^{\mathrm{h}} 2^{\mathrm{m}} 38,76^{\mathrm{s}}$ \\
\hline \multirow{4}{*}{4} & Time of Sunset \\
\hline & al-Hâsib's Method \\
\hline & $17: 44: 32,01$ \\
\hline & difference $=0^{\mathrm{h}} 5^{\mathrm{m}} 53,21^{\mathrm{s}}$ \\
\hline
\end{tabular}

Table 3. Comparison of the results between the calculation of al-Hâsib's method and Slamet Hambali's method (Ephemeris)

Based on the table 3, it can be seen that the method of determining the time with a star reference formulated by al-Hâsib has a relatively small difference compared to the time calculation based on the Sun. In author's opinion, the time difference between the two methods is caused by the Sun's altitude at rising and setting in the al-Hâsib's method is not Sun's altitude when the upper disk of the Sun touched the apparent horizon $(\text { mari } i)^{44}$ like the general definition used in Falak science books, ${ }^{45}$ but when the Sun's altitude is $0^{\circ}$. The author believed so because al-Hâsib's method uses the calculation of Nisf Qaus al-Nahâr and Nisf Qaus al-Lail which are the hour angle of the Sun when its altitude is $0^{\circ}$.

\section{C.4. Reformulation of Algorithm in Calculating Star's Position as a sign of Early Isya and Fajr Prayer Times}

In this discussion, the author offered two methods which are obtained by reformulating the methods formulated by al-Buraidi and al-Hasib, there are:

1. Culmination of stars as a sign of early Isya and Fajr prayer times

\footnotetext{
${ }^{44}$ Apparent horizon is a flat plane that is seen by the eyes of the observer as if the sky and the Earth meet, so it is usually called ufuq mar'i. See Slamet Hambali, Ilmu ..., p. 76

${ }^{45}$ Look at Slamet Hambali, Ilmu ..., p. 77
} 
This method is the development of the al-Buraidi's method which uses the culmination of Manâzil al-Qamar as a sign of the beginning of Isya and Fajr prayer times. The author reformulated al-Buraidi's method by using transformation of star's hour angle coordinate system. In Textbook on Spherical Trigonometry, it is mentioned that the important element in determining the position of stars is the value of Local Sidereal Time (LST). Local Sidereal Time can also be referred as the hour angle of vernal equinox point.

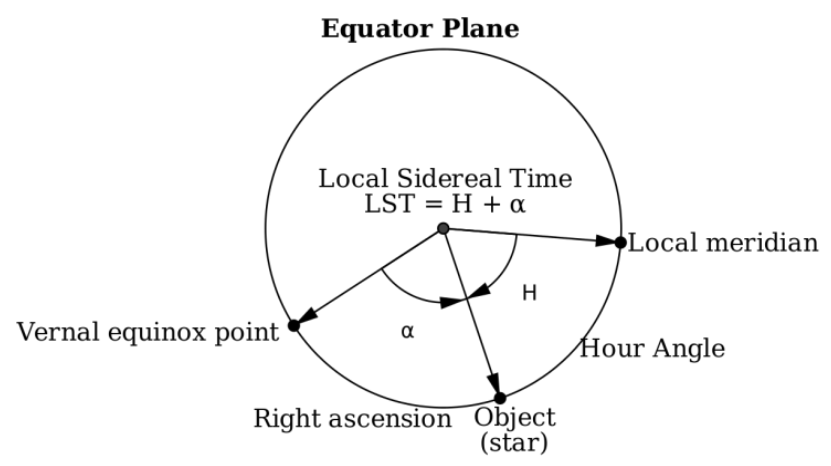

Picture 1. Illustration of Local Sidereal Time system ${ }^{46}$

In the author's opinion, Local Sidereal Time can be calculated using any celestial hour angle and its right ascension data. And at the same time, the sum of the hour angle and right ascension of any celestial bodies will result the same value of Local Sidereal Time. So from this analogy, the equation is obtained:

$$
\text { LST }=\alpha_{b}+t_{b}=\alpha_{m}+t_{m} \ldots-(\text { called equation } 1)
$$

note:

$\alpha_{\mathrm{b}}=$ star's right ascension

$\mathrm{t}_{\mathrm{b}}=$ star's hour angle

$\alpha_{\mathrm{m}}=$ sun right ascension

$\mathrm{t}_{\mathrm{m}}=$ Sun's hour angle at Isya or Fajr

This equation can also be used to generate the equation for calculating any star that is culminating at Isya and Fajr prayer time. When the star culminates,

${ }^{46}$ https://astronavigationdemystified.com/local-hour-angle-and-greenwich-hour-angle/ accessed on March 21, 2019 
the value of its hour angle is $0^{\circ}\left(t_{b}=0^{\circ}\right)$. Then the equation 1 can be changed to calculate the value of culminating star's right ascension:

$$
\begin{gathered}
\alpha_{b}+t_{b}=\alpha_{m}+t_{m} \\
\alpha_{b}+0=\alpha_{m}+t_{m} \\
\alpha_{b}=\alpha_{m}+t_{m} \ldots-(\text { called equation 2) }
\end{gathered}
$$

Based on the equation 2, the star that culminates at Isya or Fajr prayer times is a star whose right ascension value is equal to the sum of Sun's right ascension and the Sun's hour angle at Isya or Fajr prayer time or the equation 2. If there is no star whose right ascension value is equal to the equation 2 , then what is used is a star whose right ascension value is closest to equation 2 . So it is needed to perform some other calculations to find star's hour angle and its altitude. The formula that can be used are as follows:

$$
\begin{gathered}
t_{b}=\left(\alpha_{m}+t_{m}\right)-\alpha_{b x} \\
\text { or } \\
t_{b x}=\alpha_{b k}-\alpha_{b x}
\end{gathered}
$$

note:

$t_{b x}=$ hour angle of the star whose right ascension approaches the value of equation 2

$\alpha_{\mathrm{bk}}=$ star right ascension is equal to equation 2

$\alpha_{b x}=$ star right ascension whose right ascension approaches the value of equation 2

In applying the method, the author used calculation of Sun's hour angle at the Isya and Fajr from Ilmu Falak 1 by Slamet Hambali and star data from The Nautical Almanac of Stars with the following calculation details:

a. Required data:

Latitude of place $(\phi) \quad: 6^{\circ} 59^{\prime} 43^{\prime \prime} \mathrm{S}$

Longitude place $\left(\lambda_{\mathrm{t}}\right): 110^{\circ} 19^{\prime} 55^{\prime \prime} \mathrm{E}$

Elevation of place $(\mathrm{tt}) \quad$ : 59 masl

Longitude of time zone $\left(\lambda_{d}\right): 105^{\circ}$

Date : 1 April 2019 
Sun Right ascension $\left(\alpha_{\mathrm{m}}\right)$ : $10^{\circ} 16^{\prime} 50^{\prime \prime}$

Sun Declination $\left(\delta_{\mathrm{m}}\right)^{47} \quad: 4^{\circ} 25^{\prime} 25^{\prime \prime}$

Sun's altitude at Isya ${ }^{48} \quad:-17^{\circ} 32^{\prime} 31,13^{\prime \prime}$

Sun's altitude at Fajr ${ }^{49} \quad:-19^{\circ} 32^{\prime} 31,13$ ”

b. Calculate the angle of time of the Sun at Isya $\left(t_{i s}\right)$

Cost $\mathrm{t}_{\mathrm{is}} \quad=-\tan \phi \times \tan \delta_{\mathrm{m}}+\sin \mathrm{h}_{\mathrm{is}}: \cos \phi: \cos \delta_{\mathrm{m}}$

$=-\tan -6^{\circ} 59^{\prime} 43^{\prime \prime} \times \tan 4^{\circ} 25^{\prime} 25^{\prime \prime}+\sin -17^{\circ} 32^{\prime} 31,13^{\prime \prime}$

: $\cos -6^{\circ} 59^{\prime} 43^{\prime \prime}: \cos 4^{\circ} 25^{\prime} 25^{\prime \prime}$

$\mathrm{t}_{\text {is }} \quad=107^{\circ} 9^{\prime} 44,41^{\prime \prime}$

c. Calculating the angle of time of the Sun at Fajr $\left(\mathrm{t}_{\mathrm{sb}}\right)$

Cost $\mathrm{t}_{\mathrm{sb}} \quad=-\tan \phi \times \tan \delta_{\mathrm{m}}+\sin \mathrm{h}_{\mathrm{sb}}: \cos \phi: \cos \delta_{\mathrm{m}}$

$=-\tan -6^{\circ} 59^{\prime} 43^{\prime \prime} \times \tan 4^{\circ} 25^{\prime} 25^{\prime \prime}+\sin -19^{\circ} 32^{\prime} 31,13^{\prime \prime}$

$: \cos -6^{\circ} 59^{\prime} 43^{\prime \prime}: \cos 4^{\circ} 25^{\prime} 25^{\prime \prime}$

$\mathrm{t}_{\mathrm{sb}} \quad=109^{\circ} 10^{\prime} 44,46^{\prime \prime}$

$=360-109^{\circ} 10^{\prime} 44,46^{\prime \prime}$

$=250^{\circ} 49^{\prime} 15,54^{\prime \prime}$

d. Calculating star's right ascension that culminates at Isya $\left(\boldsymbol{\alpha}_{\mathrm{bk} 1}\right)$

$$
\begin{aligned}
\alpha_{\mathrm{bk} 1} & =\alpha_{\mathrm{m}}+\mathrm{t}_{\mathrm{is}} \\
& =10^{\circ} 16^{\prime} 50^{\prime \prime}+107^{\circ} 9^{\prime} 44,41^{\prime \prime} \\
& =117^{\circ} 26^{\prime} 34,41^{\prime \prime}
\end{aligned}
$$

e. Calculating star's right ascension that culminates at Fajr $\left(\alpha_{\mathrm{bk} 2}\right)$

$$
\begin{aligned}
\alpha_{\mathrm{bk} 2} & =\alpha_{\mathrm{m}}+\mathrm{t}_{\mathrm{sb}} \\
& =10^{\circ} 16^{\prime} 50^{\prime \prime}+250^{\circ} 49^{\prime} 15,54^{\prime \prime} \\
& =261^{\circ} 6^{\prime} 5,54^{\prime \prime}
\end{aligned}
$$

f. Determining the star that culminated at Isya and its correction

According to the calculations above, the star that culminates at Isya is a star that has right ascension $\alpha_{\mathrm{b} 1}=117^{\circ} 26^{\prime} 34,41$ ". The closest to that

${ }^{47}$ The value of sun's righr ascension and declination that author used was the Sun's right ascension at 12 WIB. Look at Direktorat Urusan Agama Islam dan Pembinaan Syariah, Ephemeris..., p. 125

${ }^{48}$ Sun's altitude at Isya calculated by the formula $-17-(\mathrm{sd}+\mathrm{ref}+\mathrm{dip})$. The value of refraction that used is $0^{\circ} 3^{\prime}$. Look at Slamet Hambali, Ilmu..., p. 146

${ }^{49}$ Sun's altitude at Fajr calculated in previous calculation 
value is the Pollux star whose declination value is $27^{\circ} 58,7^{\prime}$ and right ascension is $116^{\circ} 37^{\prime} 12^{\prime \prime}$.

Thus, it is necessary to calculate the hour angle of the Pollux star in order to obtain its altitude and azimuth. The formula used is as follows:

$$
\begin{array}{ll}
\mathrm{t}_{\mathrm{bx}} & =\alpha_{\mathrm{bk}}-\alpha_{\mathrm{bx}} \\
\mathrm{t}_{\mathrm{bx}} & =117^{\circ} 26^{\prime} 34,41^{\prime \prime}-116^{\circ} 37^{\prime} 12^{\prime \prime} \\
& =0^{\circ} 49^{\prime} 22,41^{\prime \prime}
\end{array}
$$

Then the altitude $\left(\mathrm{h}_{\mathrm{bx}}\right)$ and azimuth $\left(\mathrm{A} z_{\mathrm{bx}}\right)$ of Pollux at Isya prayer time is:

$$
\begin{aligned}
\sin \mathrm{h}_{\mathrm{bx}} \quad= & \sin \phi \mathrm{x} \sin \delta_{\mathrm{bx}}+\cos \phi \mathrm{x} \cos \delta_{\mathrm{bx}} \mathrm{x} \cos \mathrm{t}_{\mathrm{bx}} \\
= & \sin -6^{\circ} 59^{\prime} 43^{\prime \prime} \mathrm{x} \sin 27^{\circ} 58,7^{\prime}+\cos -6^{\circ} 59^{\prime} 43^{\prime \prime} \\
& \mathrm{x} \cos 27^{\circ} 58,7^{\prime} \mathrm{x} \cos 0^{\circ} 49^{\prime} 22,41^{\prime \prime} \\
\mathrm{h}_{\mathrm{bx}} & 55^{\circ} 1^{\prime} 2,47^{\prime \prime}
\end{aligned}
$$

While the azimuth $\left(\mathrm{Az}_{\mathrm{bx}}\right)$ of Pollux at Isya prayer time is:

$$
\begin{aligned}
\operatorname{Cotan} A_{b x}= & \tan \delta_{b x} \times \cos \phi: \sin t_{b x}-\sin \phi: \tan t_{b x} \\
= & \tan 27^{\circ} 58,7^{\prime} \times \cos -6^{\circ} 59^{\prime} 43^{\prime \prime}: \sin 0^{\circ} 49^{\prime} 22,41^{\prime \prime} \\
& -\sin -6^{\circ} 59^{\prime} 43^{\prime \prime}: \tan 0^{\circ} 49^{\prime} 22,41^{\prime \prime} \\
A_{b x} & 1^{\circ} 16^{\prime} 3,36^{\prime \prime} \\
A z_{b x} & =360-A_{b x} \\
= & 360-1^{\circ} 16^{\prime} 3,36 ” \\
A z_{b x} & =358^{\circ} 43^{\prime} 56,64^{\prime \prime}
\end{aligned}
$$

g. Determining the stars that are culminating in Fajr and its corrections

According to the calculations above, the star that culminates at Fajr is a star that has right ascension $\alpha_{\mathrm{bk} 2}=261^{\circ} 6^{\prime} 5,54^{\prime \prime}$. The closest to that value is the Shaula star whose declination value is $-37^{\circ} 6,8^{\prime}$ and right ascension is $263^{\circ} 43^{\prime} 36^{\prime \prime}$.

Thus, it is necessary to calculate the hour angle of the Pollux star in order to obtain its altitude and azimuth. The formula used is as follows:

$$
\begin{array}{ll}
t_{b x} & =\alpha_{b k}-\alpha_{b x} \\
t_{b x} & =261^{\circ} 6^{\prime} 5,54^{\prime \prime}-263^{\circ} 43^{\prime} 36^{\prime \prime}
\end{array}
$$




$$
\begin{aligned}
& =-2^{\circ} 37^{\prime} 30,46^{\prime \prime} \\
& =357^{\circ} 22^{\prime} 29,54^{\prime \prime}
\end{aligned}
$$

Then the altitude $\left(\mathrm{h}_{\mathrm{bx}}\right)$ and azimuth $\left(\mathrm{A} z_{\mathrm{bx}}\right)$ of Shaula at Fajr prayer time is:

$$
\begin{aligned}
\sin \mathrm{h}_{\mathrm{bx}}= & \sin \phi \mathrm{x} \sin \delta_{\mathrm{bx}}+\cos \phi \mathrm{x} \cos \delta_{\mathrm{bx}} \mathrm{x} \cos \mathrm{t}_{\mathrm{bx}} \\
= & \sin -6^{\circ} 59^{\prime} 43^{\prime \prime} \mathrm{x} \sin -37^{\circ} 6,8^{\prime}+\cos -6^{\circ} 59^{\prime} 43^{\prime \prime} \\
& \mathrm{x} \cos -37^{\circ} 6,8^{\prime} \mathrm{x} \cos 357^{\circ} 22^{\prime} 29,54^{\prime \prime} \\
\mathrm{h}_{\mathrm{bx}} & 59^{\circ} 47^{\prime} 14,05^{\prime \prime}
\end{aligned}
$$

While the azimuth $\left(\mathrm{Az}_{\mathrm{bx}}\right)$ of Pollux at Isya prayer time is:

$$
\begin{aligned}
\operatorname{Cotan} \mathrm{A}_{\mathrm{bx}}= & \tan \delta_{\mathrm{bx}} \mathrm{x} \cos \phi: \sin \mathrm{t}_{\mathrm{bx}}-\sin \phi: \tan \mathrm{t}_{\mathrm{bx}} \\
= & \tan -37^{\circ} 6,8^{\prime} \mathrm{x} \cos -6^{\circ} 59^{\prime} 43^{\prime \prime}: \sin 357^{\circ} 22^{\prime} 29,54^{\prime \prime} \\
& -\sin -6^{\circ} 59^{\prime} 43^{\prime \prime}: \tan 357^{\circ} 22^{\prime} 29,54^{\prime \prime} \\
\mathrm{A}_{\mathrm{bx}} & =-4^{\circ} 9^{\prime} 44,14^{\prime \prime} \\
\mathrm{A} z_{\mathrm{bx}} & =180+\mathrm{A}_{\mathrm{bx}} \\
= & 180+-4^{\circ} 9^{\prime} 44,14^{\prime \prime} \\
\mathrm{A} z_{\mathrm{bx}} & =175^{\circ} 50^{\prime} 15,86^{\prime \prime}
\end{aligned}
$$

Based on the above calculation results, it can be concluded that on April 1, 2019 at the specific location, the star that culminates at Isya is a star whose right ascension is $117^{\circ} 26^{\prime} 34.41^{\prime \prime}$. While the star that culminates at Fajr is a star whose right ascension is $261^{\circ} 6^{\prime} 5.54$ ”.

On April 1, 2019 there were no stars that had right ascension value of $117^{\circ} 26^{\prime} 34.41^{\prime \prime}$ and $261^{\circ} 6^{\prime} 5.54^{\prime \prime}$. So the author used the stars that had right ascension values close to these two values, there were Pollux and Shaula.

The Pollux star can be used as a sign of the early Isya prayer time when its altitude and Azimuth are $\mathrm{h}=55^{\circ} 0^{\prime} 2.07^{\prime \prime}$ and $\mathrm{Az}=357^{\circ} 51^{\prime}$ 28.73". While the Shaula star can be used as a sign of the early Fajr prayer time when its altitude and azimuth are $\mathrm{h}=59^{\circ} 44^{\prime} 30.92^{\prime \prime}$ and $\mathrm{Az}=174^{\circ}$ 56'33.75".

2. The altitude and azimuth of the star as a sign of early Isya and Fajr prayer times 
This second method can be a solution if there are not found stars that are bright enough and near their culmination points at Isya and Fajr prayer times. This method is a reformulation of the al-Hâsib method. In the previous discussion, the author explained that al-Hâsib's method was accurate enough to find out the time remaining from the night based on observing the altitude of a star. However, it cannot be used to determine Isya and Fajr times based on the altitude and azimuth of a star. In developing al-Hâsib's method, author used the transformation of the star's hour angle coordinate system. So that any star can be used as a sign of early Isya and Fajr prayer times when its hour angle is in accordance with the following formula calculation:

$$
t_{b} \quad=\alpha_{m}+t_{m}-\alpha_{b}
$$

note :

$\mathrm{t}_{\mathrm{b}} \quad=$ star's hour angle

$\alpha_{\mathrm{m}} \quad=$ Sun's right ascension

$\mathrm{t}_{\mathrm{m}} \quad=$ Sun's hour angle at Isya or Fajr

$\alpha_{\mathrm{b}} \quad=$ star's right ascension

This formula is obtained from equation 1 that was mentioned earlier. If the star's hour angle is already known, then the calculation of its altitude and azimuth at the beginning of Isya and Fajr prayer time can be done with the spherical trigonometry formula. The important thing to note in using this method is to select any stars that are bright enough and visible in the night sky of any specific location. Starlight can be known from the star's magnitude value. ${ }^{50}$ Meanwhile, to find out whether or not a star appears at a location, it can be known by the difference between the star's right ascension with the Sun's right ascension.

The following is a list of bright star that can be used to determine Isya prayer time:

\footnotetext{
${ }^{50}$ Star Magnitude is a scale of star brightness. The smaller the magnitude of a star, the brighter the star is. See Winardi Sutantyo, Pengantar Astrofisika: Bintang-Bintang di Alam Semesta, (Bandung: ITB Publisher, 2010), p. 56
} 


\begin{tabular}{|c|c|c|c|c|c|c|c|c|c|c|c|c|c|c|}
\hline \multirow{3}{*}{ No } & \multirow{3}{*}{ Name of star } & \multirow{3}{*}{ Mag } & \multicolumn{12}{|c|}{ Month } \\
\hline & & & $\mathrm{J}$ & $\bar{F}$ & $\mathrm{M}$ & $\mathrm{A}$ & $\mathrm{M}$ & $\mathrm{Jn}$ & $\mathrm{Jl}$ & $\mathrm{A}$ & $\mathrm{S}$ & $\mathrm{O}$ & $\mathrm{N}$ & $\mathrm{D}$ \\
\hline & & & & & C & $\mathrm{p}$ & $\mathrm{e}$ & & & g & & & & \\
\hline 1 & Sirius & $-1,46$ & $\mathrm{v}$ & $\mathrm{v}$ & $\mathrm{v}$ & $\mathrm{v}$ & $\mathrm{v}$ & $\mathrm{v}$ & & & & & & \\
\hline 2 & Canopus & $-0,74$ & $\mathrm{v}$ & $\mathrm{v}$ & $\mathrm{v}$ & $\mathrm{v}$ & $\mathrm{v}$ & & & & & & & \\
\hline 3 & Arcturus & $-0,05$ & & & & & $\mathrm{v}$ & $\mathrm{v}$ & $\mathrm{v}$ & $\mathrm{v}$ & $\mathrm{v}$ & & & \\
\hline 4 & Vega & 0,03 & & & & & & & & $\mathrm{v}$ & $\mathrm{v}$ & $\mathrm{v}$ & $\mathrm{v}$ & $\mathrm{v}$ \\
\hline 5 & Capella & 0,08 & $\mathrm{v}$ & $\mathrm{v}$ & $\mathrm{v}$ & $\mathrm{v}$ & $\mathrm{v}$ & & & & & & & $\mathrm{v}$ \\
\hline 6 & Rigel & 0,13 & $\mathrm{v}$ & $\mathrm{v}$ & $\mathrm{v}$ & $\mathrm{v}$ & $\mathrm{v}$ & & & & & & & $\mathrm{v}$ \\
\hline 7 & Procyon & 0,34 & $\mathrm{v}$ & $\mathrm{v}$ & $\mathrm{v}$ & $\mathrm{v}$ & $\mathrm{v}$ & $\mathrm{v}$ & & & & & & \\
\hline 8 & Achernar & 0,46 & $\mathrm{v}$ & $\mathrm{v}$ & $\mathrm{v}$ & & & & & & & & $\mathrm{v}$ & $\mathrm{v}$ \\
\hline 9 & Betelgeuse & 0,5 & $\mathrm{v}$ & $\mathrm{v}$ & $\mathrm{v}$ & $\mathrm{v}$ & $\mathrm{v}$ & & & & & & & \\
\hline 10 & Hadar & 0,61 & & & & & $\mathrm{v}$ & $\mathrm{v}$ & $\mathrm{v}$ & $\mathrm{v}$ & $\mathrm{v}$ & & & \\
\hline 11 & Acrux & 0,76 & & & & $\mathrm{v}$ & $\mathrm{v}$ & $\mathrm{v}$ & $\mathrm{v}$ & $\mathrm{v}$ & & & & \\
\hline 12 & Altair & 0,76 & & & & & & & & $\mathrm{v}$ & $\mathrm{v}$ & $\mathrm{v}$ & $\mathrm{v}$ & $\mathrm{v}$ \\
\hline 13 & Aldebaran & 0,86 & $\mathrm{v}$ & $\mathrm{v}$ & $\mathrm{v}$ & $\mathrm{v}$ & $\mathrm{v}$ & & & & & & & $\mathrm{v}$ \\
\hline 14 & Antares & 0,96 & & & & & & & $\mathrm{v}$ & $\mathrm{v}$ & $\mathrm{v}$ & $\mathrm{v}$ & $\mathrm{v}$ & \\
\hline 15 & Spica & 0,97 & & & & & $\mathrm{v}$ & $\mathrm{v}$ & $\mathrm{v}$ & $\mathrm{v}$ & $\mathrm{v}$ & & & \\
\hline 16 & Pollux & 1,14 & & $\mathrm{v}$ & $\mathrm{v}$ & $\mathrm{v}$ & $\mathrm{v}$ & $\mathrm{v}$ & & & & & & \\
\hline 17 & Fomalhaut & 1,16 & $\mathrm{v}$ & $\mathrm{v}$ & & & & & & $\mathrm{v}$ & & $\mathrm{v}$ & $\mathrm{v}$ & $\mathrm{v}$ \\
\hline 18 & Deneb & 1,2 & & & & & & & & & $\mathrm{v}$ & $\mathrm{v}$ & $\mathrm{v}$ & $\mathrm{v}$ \\
\hline 19 & Regulus & 1,39 & & & $\mathrm{v}$ & $\mathrm{v}$ & $\mathrm{v}$ & $\mathrm{v}$ & $\mathrm{v}$ & & & & & \\
\hline 20 & Adhara & 1,5 & $\mathrm{v}$ & $\mathrm{v}$ & $\mathrm{v}$ & $\mathrm{v}$ & $\mathrm{v}$ & $\mathrm{v}$ & & & & & & \\
\hline 21 & Shaula & 1,62 & & & & & & & $\mathrm{v}$ & $\mathrm{v}$ & $\mathrm{v}$ & $\mathrm{v}$ & $\mathrm{v}$ & \\
\hline
\end{tabular}

Table 4. List of stars seen in the Semarang sky at Isya

The following is a list of bright star names and can be used to determine Fajr prayer time:

\begin{tabular}{|c|c|c|c|c|c|c|c|c|c|c|c|c|c|c|}
\hline \multirow[b]{2}{*}{ No } & \multirow[b]{2}{*}{ Name of star } & \multirow[b]{2}{*}{ Mag } & \multicolumn{12}{|c|}{ Month } \\
\hline & & & $\mathrm{J}$ & $\mathrm{F}$ & $\begin{array}{l}\mathrm{M} \\
\mathrm{a}\end{array}$ & $\begin{array}{l}\mathrm{A} \\
\mathrm{p}\end{array}$ & $\begin{array}{l}\mathrm{M} \\
\mathrm{e}\end{array}$ & $\mathrm{Jn}$ & $\mathrm{Jl}$ & $\begin{array}{l}\text { A } \\
\mathrm{g}\end{array}$ & $S$ & $\mathrm{O}$ & $\mathrm{N}$ & $\mathrm{D}$ \\
\hline 1 & Sirius & $-1,46$ & $\mathrm{v}$ & & & & & & & & $\mathrm{v}$ & $\mathrm{v}$ & $\mathrm{v}$ & $\mathrm{v}$ \\
\hline 2 & Canopus & $-0,74$ & & & & & & & & $\mathrm{v}$ & $\mathrm{v}$ & $\mathrm{v}$ & $\mathrm{v}$ & $\mathrm{v}$ \\
\hline 3 & Arcturus & $-0,05$ & $\mathrm{v}$ & $\mathrm{v}$ & $\mathrm{v}$ & $\mathrm{v}$ & & & & & & & & $\mathrm{v}$ \\
\hline 4 & Vega & 0,03 & & $\mathrm{v}$ & $\mathrm{v}$ & $\mathrm{v}$ & $\mathrm{v}$ & $\mathrm{v}$ & & & & & & \\
\hline 5 & Capella & 0,08 & & & & & & & & $\mathrm{v}$ & $\mathrm{v}$ & $\mathrm{v}$ & $\mathrm{v}$ & $\mathrm{v}$ \\
\hline 6 & Rigel & 0,13 & & & & & & & & $\mathrm{v}$ & $\mathrm{v}$ & $\mathrm{v}$ & $\mathrm{v}$ & $\mathrm{v}$ \\
\hline 7 & Procyon & 0,34 & $\mathrm{v}$ & & & & & & & & $\mathrm{v}$ & $\mathrm{v}$ & $\mathrm{v}$ & $\mathrm{v}$ \\
\hline 8 & Achernar & 0,46 & & & & & & $\mathrm{v}$ & $\mathrm{v}$ & $\mathrm{v}$ & $\mathrm{v}$ & $\mathrm{v}$ & & \\
\hline 9 & Betelgeuse & 0,5 & & & & & & & & $\mathrm{v}$ & $\mathrm{v}$ & $\mathrm{v}$ & $\mathrm{v}$ & $\mathrm{v}$ \\
\hline 10 & Hadar & 0,61 & $\mathrm{v}$ & $\mathrm{v}$ & $\mathrm{v}$ & $\mathrm{v}$ & & & & & & & & $\mathrm{V}$ \\
\hline 11 & Acrux & 0,76 & $\mathrm{v}$ & $\mathrm{v}$ & $\mathrm{v}$ & & & & & & & & & $\mathrm{v}$ \\
\hline 12 & Altair & 0,76 & & & $\mathrm{v}$ & $\mathrm{v}$ & $\mathrm{v}$ & $\mathrm{v}$ & $\mathrm{v}$ & & & & & \\
\hline 13 & Aldebaran & 0,86 & & & & & & & $\mathrm{v}$ & $\mathrm{v}$ & $\mathrm{v}$ & $\mathrm{v}$ & $\mathrm{v}$ & $\mathrm{v}$ \\
\hline 14 & Antares & 0,96 & $\mathrm{v}$ & $\mathrm{v}$ & $\mathrm{v}$ & $\mathrm{v}$ & $\mathrm{v}$ & & & & & & & \\
\hline 15 & Spica & 0,97 & $\mathrm{v}$ & $\mathrm{v}$ & $\mathrm{v}$ & $\mathrm{v}$ & & & & & & & & $\mathrm{v}$ \\
\hline 16 & Pollux & 1,14 & $\mathrm{v}$ & & & & & & & & $\mathrm{v}$ & $\mathrm{v}$ & $\mathrm{v}$ & $\mathrm{v}$ \\
\hline 17 & Fomalhaut & 1,16 & & & & & $\mathrm{~V}$ & $\mathrm{~V}$ & $\mathrm{v}$ & $\mathrm{v}$ & $\mathrm{v}$ & & & \\
\hline 18 & Deneb & 1,2 & & & $\mathrm{v}$ & $\mathrm{v}$ & $\mathrm{v}$ & $\mathrm{v}$ & $\mathrm{v}$ & & & & & \\
\hline 19 & Regulus & 1,39 & $\mathrm{v}$ & $\mathrm{v}$ & & & & & & & & $\mathrm{v}$ & $\mathrm{v}$ & $\mathrm{v}$ \\
\hline 20 & Adhara & 1,5 & $\mathrm{v}$ & & & & & & & & $\mathrm{V}$ & $\mathrm{v}$ & $\mathrm{v}$ & $\mathrm{v}$ \\
\hline
\end{tabular}




\begin{tabular}{l|l|r|r|l|l|l|l|l|l|l|l|l|l|l}
\hline 21 & Shaula & 1,62 & & v & v & v & v & v & & & & & & \\
\hline
\end{tabular}

Table 5. List of stars seen in the Semarang sky at Fajr

The steps to use this method are as follows:

a. Required data:

Latitude of place $(\phi) \quad: 6^{\circ} 59^{\prime} 43^{\prime \prime} \mathrm{S}$

Longitude of place $\left(\lambda_{\mathrm{t}}\right) \quad$ : $110^{\circ} 19^{\prime} 55^{\prime \prime} \mathrm{E}$

Elevation of place $(\mathrm{tt}) \quad$ : 59 masl

Longitude of time zone $\left(\lambda_{\mathrm{d}}\right): 105^{\circ}$

Date : :6 April 2019

Sun's right ascension $\left(\alpha_{\mathrm{m}}\right)$ : $14^{\circ} 50^{\prime} 42^{\prime \prime}$

Sun's declination $\left(\delta_{\mathrm{m}}\right)^{51} \quad: 6^{\circ} 20^{\prime} 14^{\prime \prime}$

b. Determining the star used as a sign of Isya and Fajr time

The first step that must be done is to determine one or two stars that can be seen in the sky at Isya and Fajr so that they can be used as time markers for Isya and Fajr. This can be done by looking at table 4 and table 5. In this calculation, the author used the Sirius star in determining Isya time and the Vega star in determining the Fajr time. The following is the right ascension and declination of the two stars:

\begin{tabular}{|l|l|l|}
\hline Name of star & Right ascension & Declination \\
\hline Sirius & $101^{\circ} 29^{\prime} 42^{\prime \prime}$ & $-16^{\circ} 44,9^{\prime}$ \\
\hline Vega & $279^{\circ} 23^{\prime} 42^{\prime \prime}$ & $38^{\circ} 47,9^{\prime}$ \\
\hline
\end{tabular}

Table 6. Star ascension and declination data ${ }^{52}$

c. Calculating Sun's hour angle at Isya time

$$
\begin{aligned}
\text { Cost }_{\mathrm{is}}= & -\tan \phi \times \tan \delta_{\mathrm{m}}+\sin \mathrm{h}_{\mathrm{is}}: \cos \phi: \cos \delta_{\mathrm{m}} \\
= & -\tan -6^{\circ} 59^{\prime} 43^{\prime \prime} \times \tan 6^{\circ} 20^{\prime} 14^{\prime \prime}+\sin -17^{\circ} 32^{\prime} 31,13^{\prime \prime} \\
& : \cos 6^{\circ} 59^{\prime} 43^{\prime \prime}: \cos 6^{\circ} 20^{\prime} 14^{\prime \prime} \\
\mathrm{t}_{\mathrm{is}} & 106^{\circ} 58^{\prime} 19,32^{\prime \prime}
\end{aligned}
$$

d. Calculating the hour angle of Sirius at Isya prayer time

${ }^{51}$ The value of sun's righr ascension and declination that author used was the Sun's right ascension at 12 WIB. Look at Direktorat Urusan Agama Islam dan Pembinaan Syariah, Ephemeris..., p. 130

${ }^{52}$ In the Nautical Almanac of Stars, the position of a star is presented with two data, namely: SHA and declination. to change SHA to right ascension by: 360-SHA. See Enno Rodegerdts, The Nautical Almanac of Stars, (London: HM Nautical Almanac Office, 2019), p. 97 
The hour angle of Sirius star can be calculated by deriving equation 1 or the LST equation that is explained before:

$$
\text { LST }=\alpha_{b}+t_{b}=\alpha_{m}+t_{m}
$$

So, the hour angle of Sirius at Isya:

$\mathrm{t}_{\mathrm{b}} \quad=\alpha_{\mathrm{m}}+\mathrm{t}_{\mathrm{m}}-\alpha_{\mathrm{b}}$

$=14^{\circ} 50^{\prime} 42^{\prime \prime}+106^{\circ} 58^{\prime} 19,32^{\prime \prime}-101^{\circ} 29^{\prime} 42^{\prime \prime}$

$\mathrm{t}_{\mathrm{b}} \quad=20^{\circ} 19^{\prime} 19,32^{\prime}$

e. Calculating the altitude and azimuth of Sirius at Isya

The altitude of Sirius at Isya prayer time can be calculated by the following formula:

$\operatorname{Sin} \mathrm{h}_{\mathrm{b}} \quad=\sin \phi \mathrm{x} \sin \delta_{\mathrm{b}}+\cos \phi \mathrm{x} \cos \delta_{\mathrm{b}} \mathrm{x} \cos \mathrm{t}_{\mathrm{b}}$

$=\sin -6^{\circ} 59^{\prime} 43^{\prime \prime} \times \sin -16^{\circ} 44,9^{\prime}+\cos -6^{\circ} 59^{\prime} 43^{\prime \prime}$

$x \cos -16^{\circ} 44,9^{\prime} x \cos 20^{\circ} 19^{\prime} 19,32^{\prime \prime}$

$\mathrm{h}_{\mathrm{b}} \quad=67^{\circ} 52^{\prime} 42,16^{\prime \prime}$

The direction of Sirius at Isya prayer time can be calculated by the following formula:

$$
\begin{aligned}
\operatorname{Cotan} A_{b}= & \tan \delta_{b} \times \cos \phi: \sin t_{b}-\sin \phi: \tan t_{b} \\
= & \tan -16^{\circ} 44,9^{\prime} \times \cos -6^{\circ} 59^{\prime} 43^{\prime \prime}: \sin 20^{\circ} 19^{\prime} 19,32^{\prime \prime} \\
& -\sin -6^{\circ} 59^{\prime} 43^{\prime \prime}: \tan 20^{\circ} 19^{\prime} 19,32^{\prime \prime}
\end{aligned}
$$

$\mathrm{A}_{\mathrm{b}} \quad=-62^{\circ} 1^{\prime} 20,41^{\prime \prime}$

Because of the direction of Sirius is negative and its hour angle is positive or between $0-180^{\circ}$, so the direction is calculated $62^{\circ} 1^{\prime} 20,41^{\prime \prime}$ from South to West. So the azimuth of Sirius is:

$$
\begin{aligned}
\mathrm{A} z_{\mathrm{b}} & =180-\mathrm{A}_{\mathrm{b}} \\
& =180--62^{\circ} 1^{\prime} 20,41^{\prime \prime} \\
\mathrm{A} z_{\mathrm{b}} & =242^{\circ} 1^{\prime} 20,41^{\prime \prime}
\end{aligned}
$$

f. Calculating the Sun's hour angle at Fajr prayer time

In this method, the Sun's hour angle must use a system of hour angles calculated from meridian circles in a clockwise direction or with a range angle of $0^{\circ}-360^{\circ}$. Thus, the Sun's hour angle at Fajr prayer time is 
calculated using the spherical trigonometry formula, the value must be changed to a range angle from $180^{\circ}$ to $360^{\circ}$. The formula used is as follows:

$$
\begin{aligned}
\operatorname{Cost}_{\mathrm{sb}}= & -\tan \phi \times \tan \delta_{\mathrm{m}}+\sin \mathrm{h}_{\mathrm{sb}}: \cos \phi: \cos \delta_{\mathrm{m}} \\
= & -\tan -6^{\circ} 59^{\prime} 43^{\prime \prime} \times \tan 6^{\circ} 20^{\prime} 14^{\prime \prime}+\sin -19^{\circ} 32^{\prime} 31,13^{\prime \prime} \\
& : \cos -6^{\circ} 59^{\prime} 43^{\prime \prime}: \cos 6^{\circ} 20^{\prime} 14^{\prime \prime} \\
\mathrm{t}_{\mathrm{sb}} \quad & 108^{\circ} 59^{\prime} 34,44^{\prime \prime} \\
= & 360-108^{\circ} 59^{\prime} 34,44^{\prime \prime} \\
= & 251^{\circ} 0^{\prime} 25,56^{\prime \prime}
\end{aligned}
$$

g. Calculating the hour angle of Vega star at Fajr prayer time

The hour angle of Vega star can be calculated by deriving equation 1 or the LST equation that is explained before:

$$
\text { LST }=\alpha_{b}+t_{b}=\alpha_{m}+t_{m}
$$

So, the hour angle of Vega at Fajr:

$t_{b}$

$=\alpha_{m}+t_{m}-\alpha_{b}$

$=14^{\circ} 50^{\prime} 42^{\prime \prime}+251^{\circ} 0^{\prime} 25,56^{\prime \prime}-279^{\circ} 23^{\prime} 42^{\prime \prime}$

$t_{b}$

$=-13^{\circ} 32^{\prime} 34,44^{\prime \prime}$

$=346^{\circ} 27^{\prime} 25,56^{\prime \prime}$

h. Calculating the altitude and azimuth of Vega at Fajr

The altitude of Vega at Fajr prayer time can be calculated by the following formula:

$\sin \mathrm{h}_{\mathrm{b}} \quad=\sin \phi \mathrm{x} \sin \delta_{\mathrm{b}}+\cos \phi \mathrm{x} \cos \delta_{\mathrm{b}} \mathrm{x} \cos \mathrm{t}_{\mathrm{b}}$

$=\sin -6^{\circ} 59^{\prime} 43^{\prime \prime} \mathrm{x} \sin 38^{\circ} 47,9^{\prime}+\cos -6^{\circ} 59^{\prime} 43^{\prime \prime}$

$x \cos 38^{\circ} 47,9^{\prime} x \cos 346^{\circ} 27^{\prime} 25,56^{\prime \prime}$

$\mathrm{h}_{\mathrm{b}} \quad=42^{\circ} 30^{\prime} 40,86^{\prime \prime}$

The direction of Vega at Fajr prayer time can be calculated by the following formula:

$$
\begin{aligned}
\operatorname{Cotan} A_{b}= & \tan \delta_{b} \times \cos \phi: \sin t_{b}-\sin \phi: \tan t_{b} \\
= & \tan 38^{\circ} 47,9^{\prime} \times \cos -6^{\circ} 59^{\prime} 43^{\prime \prime}: \sin 346^{\circ} 27^{\prime} 25,56^{\prime \prime} \\
& -\sin -6^{\circ} 59^{\prime} 43^{\prime \prime}: \tan 346^{\circ} 27^{\prime} 25,56^{\prime \prime}
\end{aligned}
$$


$\mathrm{A}_{\mathrm{b}} \quad=-14^{\circ} 48^{\prime} 4,39^{\prime \prime}$

Because of the declination of the Vega star is greater than the latitude of the place and its hour angle is negative or between $180^{\circ}-360^{\circ}$, so the direction is calculated $14^{\circ} 48^{\prime} 4,39$ " from North to East. So the azimuth of Vega is:

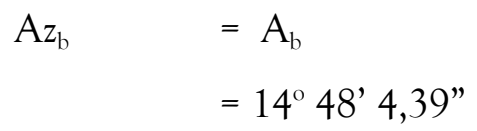

Based on the above calculation results, it can be concluded that on April 1, 2019 at the specific location, Sirius star can be used as a sign of early Isya prayer time when its altitude and azimuth are $h=67^{\circ} 52^{\prime} 42,16^{\prime \prime}$ and $A z=242^{\circ} 1^{\prime} 20,41^{\prime \prime}$. Meanwhile Vega star can be used as a sign of early Fajr prayer time when its height and azimuth are $h=42^{\circ} 30^{\prime} 40,86^{\prime \prime}$ and $\mathrm{Az}=14^{\circ} 48^{\prime} 4,39^{\prime \prime}$.

\section{C.5. Accuracy Test of The Reformulation Result on Star's Position Calculation} Algorithm as The Sign of Early Isya and Fajr Time

The Reformulation of algorithm for calculating star's position as a sign of early of Isya and Fajr prayer times that has been described in the previous discussion, requires testing with observation to determine its accuracy. The test can be done by aiming the telescope, theodolite or other observation tools for the stars that have been determined at the beginning of Isya and Fajr time.

In this test, the author could only make observations at Fajr on April 6 and 7, 2019 using theodolite at locations with coordinates: 6 59'6 59' 43” S, 110 19' 55" E dan 59 masl. As for the data used as a reference for the sign of Fajr prayer time are as follows:

\begin{tabular}{lllll}
\hline Date & Name of star & Altitude & Zenith's distance & Azimuth \\
\hline $06 / 04 / 2019$ & Vega & $42^{\circ} 30^{\prime} 40,86^{\prime \prime}$ & $47^{\circ} 28^{\prime} 12,94^{\prime \prime}$ & $14^{\circ} 48^{\prime} 4,39^{\prime \prime}$ \\
\hline $07 / 04 / 2019$ & Rigil Kent & $26^{\circ} 19^{\prime} 21,79^{\prime \prime}$ & $63^{\circ} 38^{\prime} 34,26^{\prime \prime}$ & $203^{\circ} 0^{\prime} 34,71^{\prime \prime}$ \\
\hline
\end{tabular}

Table 7. Star's position data as a sign of Fajr prayer time 
In the first test on April 6, 2019, the author used the Vega star as a sign of early Fajr prayer time. The observation of Vega star was carried out at the beginning of Fajr prayer time at 04:25 WIB. The following are the results of the test:
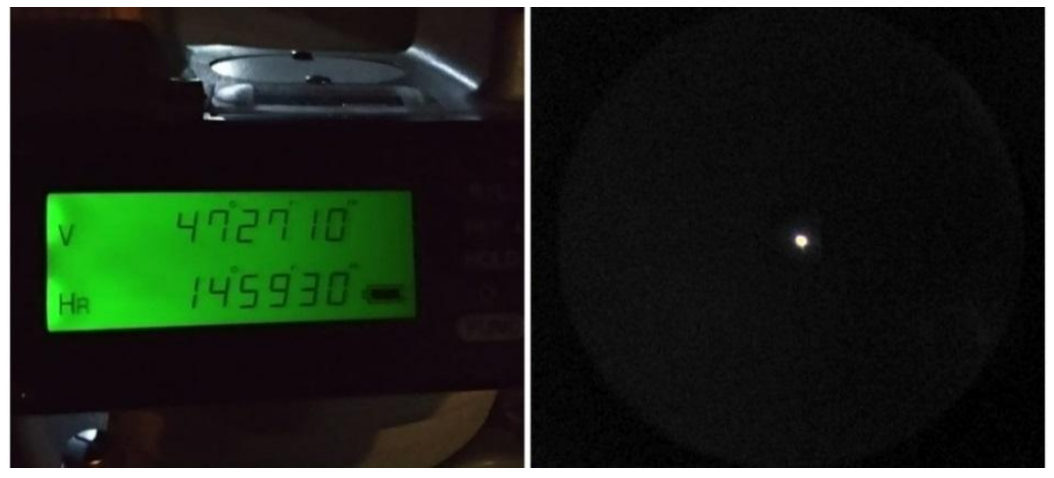

Picture 2. VA and HA values on Theodolite that aimed for Vega star at early Fajr prayer time ${ }^{53}$

\begin{tabular}{lllll}
\hline No & Method & Name of star & $\begin{array}{c}\text { Zenith's distance } \\
\text { (VA) }\end{array}$ & Azimuth (HA) \\
\hline 1 & Calculation & Vega & $47^{\circ} 28^{\prime} 12,94^{\prime \prime}$ & $14^{\circ} 48^{\prime} 4,39^{\prime \prime}$ \\
\hline 2 & Observation & Vega & $47^{\circ} 27^{\prime} 10^{\prime \prime}$ & $14^{\circ} 59^{\prime} 30^{\prime \prime}$ \\
\hline \multicolumn{2}{c}{ Difference } & $0^{\circ} 1^{\prime} 2,94^{\prime \prime}$ & $0^{\circ} 11^{\prime} 25,61^{\prime \prime}$ \\
\hline
\end{tabular}

Table 8. Comparison of the results between calculation and observation of

Vega star

In the second test on 7 April 2019, the author used the star Rigil Kent, as a sign of early Fajr prayer time. The observation of Rigil Kent star was carried out at the beginning of Fajr prayer time at 04:25 WIB.
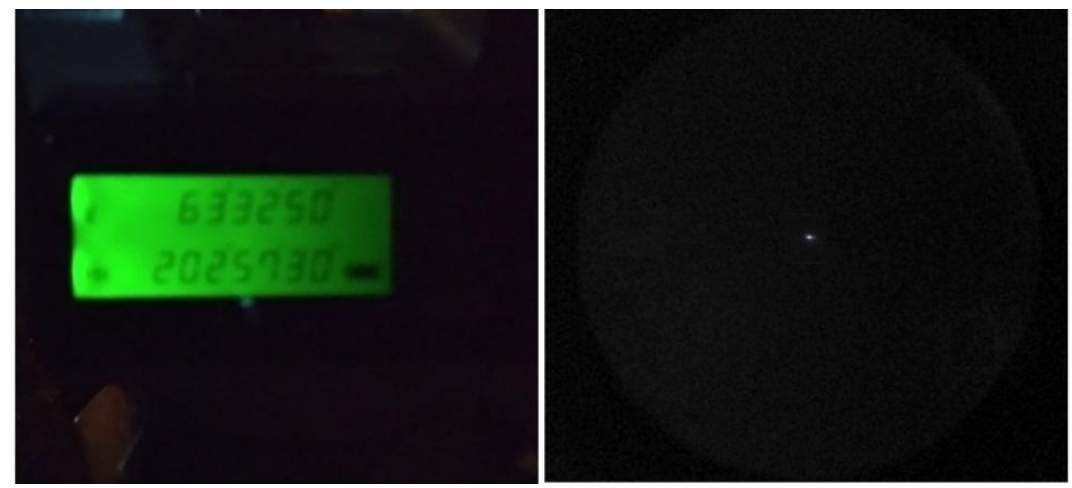

Picture 3. Display of VA and HA values on Theodolite when shooting Rigil

\section{Kent stars at Fajr}

${ }^{53} \mathrm{VA}$ or Vertical Angle is the angle value along the vertical circle of the globe that is calculated from the zenith to the position targeted by the Theodolite scope. While HA or Horizontal Angle is the angle value along the horizon circle which is calculated from the $0^{\circ}$ position of setting the Theodolite to the position targeted by the Scope Theodolite. 


\begin{tabular}{|c|c|c|c|c|}
\hline $\mathrm{No}$ & Method & Name of star & $\begin{array}{c}\text { Zenith's distance } \\
\text { (VA) }\end{array}$ & Azimuth (HA) \\
\hline 1 & Calculation & Rigil Kent. & $63^{\circ} 38^{\prime} 34,26^{\prime \prime}$ & $203^{\circ} 0^{\prime} 34,71^{\prime \prime}$ \\
\hline 2 & Observation & Rigil Kent. & $63^{\circ} 32^{\prime} 50^{\prime \prime}$ & $202^{\circ} 57^{\prime} 30^{\prime \prime}$ \\
\hline \multicolumn{3}{|c|}{ Difference } & $0^{\circ} 5^{\prime} 44,36 ”$ & $0^{\circ} 10^{\prime} 4,71 "$ \\
\hline
\end{tabular}

Table 9. Comparison of the results between calculation and observation of Rigil Kent star

The test results that were done show that the reformulation of algorithm in this paper is proved to be quite accurate because the difference of the angle between calculation with observation is less than 1 degree. If the difference of angle is converted to unite of time, then the difference between the determination of Fajr prayer time using star and clock or in reality will not take more than 1 minute of hour. This difference is most likely due to the Sun's right ascension that used is its value at 12 WIB. In addition, the difficulty of aiming the Theodolite's scope to the star also might be the major factor.

\section{Conclusions}

The Reformulation of algorithm for calculating star's position as a sign of early of Isya and Fajr prayer times is an alternative method that can be used in locations with limited field of view that cannot see Western and Eastern horizons and cannot have other adequate timepieces. The reformulation that the author conducted was an effort to improve the accuracy of the method for calculating the star's position as the sign of early Isya and Fajr prayer times which had been formulated by Falak experts and Muslim astronomers which had been forgotten. In this paper, the author only wrote the method of determining the time using the stars from two manuscripts that were not discussed in the researches belonging to David A. King and Julio Samso. Both manuscripts or books that researched in this paper are Risâlah fî al-Burûj wa al-Manâzil by Muhammad bin Muhammad al-Buraidî and Nuzhah al-Nâzir fî Talkhîs Zîj Ibn al-Syâtir by Ahmad bin Ghulâmillah bin Ahmad al-Hâsib.

In this paper, the author offered two methods which are obtained by reformulating the methods formulated by al-Buraidî and al-Hâsib, there are: culmination of stars as a sign of early Isya and Fajr prayer times and the altitude-azimuth of the star as a sign of early Isya and Fajr prayer times. For formulating both methods, the author used the transformation of star's hour angle coordinate system. The author 
also used some analogies on LST equation and derived the equation to obtain the reformulation of star's position calculation algorithms. Then the result of this algorithmic reformulation is tested by observing stars that can be used to determine early Isya and Fajr prayer time.

The observation test results show that the reformulation of algorithm for calculating star's position as a sign of early of Isya and Fajr prayer times is quite accurate to be used in the present time. The observation test shows that this reformulation of algoritm has the level of accuracy less than 1 degree on altitude and less than 1 minute of hour on Isya and Fajr prayer time. However, the application of the reformulation of algorithm for calculating the star's position as the sign of early Isya and Fajr prayer times requires accurate observation tool to determine the altitude of star, such as Theodolite, Sextan, and others. 


\section{E. Bibliography}

al-Buraidî, Muhammad bin Muhammad, Risâlah fî al-Burûj wa al-Manâzil; Farâid Jauhariyah fî Fawâid al-Mîqâtiyah, Manuskrip, discan oleh Library of Congress, 1831

al-Hajâwî, Syaraf al-Dîn Abû al-Najâ Mûsâ bin Ahmad, Zâd al-Mustaqni' fi ikhtisâr alMuqni', Riyadl: Madâr al-Wathn, tt.

al-Hâsib, Ahmad bin Ghulâmillah bin Ahmad, Nuzhah al-Nâzir fî̀ Talkhîs Zîj Ibn alSyâtir, Manuskrip discan oleh Library of Congress, Boston.

al-Jailani, Zubair Umar, al-Khulâsah al-Wafiyah, Kudus: Menara Kudus, tt.

al-Marâgî, Ahmad Mustafâ, Tafsîr al-Marâgî, Kairo: Maktabah Mustafâ al-Bâbî al-Halabî, tth, Juz 7

al-Misrî, Jamâl al-Dîn Muhammad bin Mukrim bin Manz ûr al-Ifrîqî, Lisân al-'Arab, Beirut: Dâr Sâdir, 2010, Jilid 10

al-Naisâbûrî, Abu al-Husain Muslim bin al-Hajjâj al-Qusyairî, Sahîh Muslim, Beirut: Dâr Ihyâ al-Turâs \al-Arabiyah, 2010, Juz 1

al-Qarafî, Syihâb al-Dîn Ahmad bin Idrîs bin abd al-Rahmân al-Sanhâjî, Anwâr al-Burûq fì anwâ al-Furûq, Kairo: Dar Ihya al-Kutub al-'Arabiyah, 2010, Juz 4

al-Ru'yanî, Muhammad Abû Abdillâh bin Muhammad al-Hattab, Mawâhib al-Jalîl li Syarh Mukhtsar al-Khalîl, Beirut: Dar al-Fikr, 1992, Juz 3

al-Sijistânî, Abû Dâwûd Sulaimân bin al-Asy'as, Sunan Abî Dâwûd, Riyad: Maktabah alMa'ârif li al-Nasyr wa al-Tauzî', 1988

al-Tahanawi, Muhammad 'Ali, Kasyâf Istilâhât al-Funûn wa al'Ulûm, Beirut: Maktabah Lubnan Nasyirun, 1996, Juz II 
al-Tibrîzî, Muhammad bin Abdullah al-Khatîb, Syarh Misykâh al-Masâbîh, Beirut: Dar alKutub al-Ilmiyah, 2001, Juz 2.

Angelo, Joseph A., Encyclopedia of Space and Astronomy, New York: Fact On File, inc, 2006

Azhari, Susiknan, Ensiklopedi Hisab Rukyat, Yogyakarta: Pustaka Pelajar, 2012, cet. III,

Butar, Arwin Juli Rakhmadi Butar, Khazanah Astronomi Islam Abad Pertengahan, Purwokerto: UM Purwokerto Press, 2016

Departemen Agama RI, Al-Qur'an dan Terjemahnya, Jakarta: CV Darus Sunnah, 2007

Departemen Pendidikan Nasional, Kamus Besar Bahasa Indonesia, Jakarta: Pusat Bahasa, 2008

Direktorat Urusan Agama Islam dan Pembinaan Syariah, Ephemeris Hisab Rukyat 2019, Jakarta: Kementerian Agama RI, 2018

Hambali, Slamet, Ilmu Falak 1, Semarang: Program Pascasarjana IAIN Walisongo Semarang, Cet. I, 2011

Izzuddin, Ahmad, Fiqih Hisab Rukyah, Jakarta: Penerbit Erlangga, 2007

King, David A., In Synnchrony with the Heavens Vol. I: The Call of The Muezzin, Leiden: Koninklijke Brill NV, 1990 , "Mikat", in The Encyclopedia of Islam, Edisi II, Leiden: Koninklijke Brill NV, 1990

Masood, Ehsan, Ilmuwan-Ilmuwan Muslim Pelopor Hebat di Bidang Sains Modern, Terjemah: Fahmy Yamani, Jakarta: PT Gramedia Pustaka Utama, 2009 
Muslifah, Siti, "Telaah Kritis Syafaqul Ahmar dan Syafaqul Abyadl Terhadap Akhir Maghrib dan Awal Isya”, Elfalaky Jurnal Ilmu Falak, Vol. 1, No. 1, (2007): $25-45$

Rodegerdts, Enno, The Nautical Almanac of Stars, London: HM Nautical Almanac Office, 2019

Samso, Julio, "Lunar Mansions and Time Keeping in Western Islam”, Suhayl Journal for the history of the exact and natural sciences in Islamic Civilisation, Vol. 8, (2008):121-161

Smart, W.M., Textbook on Spherical Trigonometry, London: Cambridge University Press, 1977

Sutantyo, Winardi, Pengantar Astrofisika: Bintang-Bintang di Alam Semesta, Bandung: Penerbit ITB, 2010

https://astronavigationdemystified.com/local-hour-angle-and-greenwich-hour-angle/

http://www.constellationsofwords.com/stars.html

https://www.iau.org/public/themes/constellations/ 